\title{
Calcareous benthic foraminifera from the upper central Peruvian margin: control of the assemblage by pore water redox and sedimentary organic matter
}

\author{
Jorge Cardich ${ }^{1,2,3, *}$, Dimitri Gutiérrez ${ }^{1,2}$, Dennis Romero ${ }^{1,2}$, Alexander Pérez ${ }^{1,2}$, \\ Luis Quipúzcoa ${ }^{2}$, Robert Marquina ${ }^{2}$, Williams Yupanqui ${ }^{2}$, Juana Solís ${ }^{2}$, Wilson \\ Carhuapoma $^{2}$, Abdelfettah Sifeddine ${ }^{3,4}$, Anthony Rathburn ${ }^{5}$
}

${ }^{1}$ Programa de Maestría en Ciencias del Mar, Universidad Peruana Cayetano Heredia, Av. Honorio Delgado 430, Lima 31, Peru ${ }^{2}$ Dirección General de Investigaciones Oceanográficas y Cambio Climático, Instituto del Mar del Perú (IMARPE), Av. Gamarra y Gral. Valle, s/n, Chucuito, Callao 01, Peru

${ }^{3}$ Departamento de Geoquimica, Universidade Federal Fluminense, LMI PALEOTRACES, Niteroi, RJ 24020-141, Brazil

${ }^{4}$ Centre IRD France-Nord, LOCEAN, UMR 7159, 32 Avenue Henri Varagnat, 93143 Bondy cedex, France

${ }^{5}$ Geology Program, Indiana State University, Science Building 159, Terre Haute, Indiana 47809, USA

\begin{abstract}
We studied 'living' (stained) benthic foraminifera in the upper border of the Peruvian oxygen minimum zone (OMZ) to determine the relationship between species' distribution and pore water and sediment geochemistry under oxygen deficiency. Superficial sediments were sampled between 2009 and 2011 from 2 bathymetric transects off central Peru ( 45 to $300 \mathrm{~m}$ depth). The quantity (total organic carbon, total nitrogen and chloroplastic pigment equivalents [CPE]) and quality (chlorophyll a/phaeopigments ratio) of organic matter (OM) were evaluated. Benthic foraminifera were sampled in the top $5 \mathrm{~cm}$ of sediment. Commonly, the inner shelf sediments were sulfidic and labile OM-rich, whereas the outer shelf and upper slope sediments exhibited postoxic conditions (e.g. anoxic and non-sulfidic) with less labile OM, typical of OMZ core sediments. Mixed conditions were found in shelf sediment samples from April 2010, when the effects of El Niño 2009/2010 were withdrawing. Foraminiferal assemblages exhibited differences according to redox conditions and OM quality, and were concentrated in the topmost sediment. A canonical correspondence analysis and non-parametric correlations indicated that Bolivina costata, Nonionella auris and Virgulinella fragilis were characteristic of sulfidic/labile OM sediments, thriving slightly deeper in the sediment. In contrast, Bolivina pacifica headed the assemblage representative of postoxia/less labile OM. Bolivina seminuda and Buliminella tenuata (both dominant under postoxia) were not associated with any specific measured parameter, although were present in sulfidic sediments, suggesting other factors were involved in their distribution.
\end{abstract}

KEY WORDS: Benthic foraminifera $\cdot$ Anoxia $\cdot$ Sulfide $\cdot$ Labile organic matter Resale or republication not permitted without written consent of the publisher

\section{INTRODUCTION}

Benthic foraminifera are protists that are abundant in the marine realm, and play a primary role in the initial breakdown and cycling of organic carbon in sediments (Woulds et al. 2007), including oxygen- deficient settings such as oxygen minimum zones (OMZs, Enge et al. 2014). Several studies (e.g. Phleger \& Soutar 1973, Bernhard et al. 1997, Gooday et al. 2000, Schumacher et al. 2007) have indicated that benthic foraminifera in OMZ sediments present elevated densities, low diversity, strong dominance of 
specialist taxa and a shallow microhabitat as a response to high labile organic matter (OM) availability and intense oxygen deficiency.

The distribution of benthic foraminifera in sediments and the dynamic nature of their microhabitat are described in the conceptual TRophic OXygen model (TROX) by Jorissen et al. (1995). This model suggests that the in-sediment distribution is controlled by sediment redox conditions and OM supply. In mesotrophic to oligotrophic conditions, the quality of sedimentary $\mathrm{OM}$ is the main factor controlling species' composition and microhabitat distribution, with pore water oxygen playing a secondary role (Eberwein \& Mackensen 2006, Fontanier et al. 2008, Koho et al. 2008, Contreras-Rosales et al. 2012). Consistent with the TROX model, benthic foraminifera are found deeper in the sediment when food is available at those depths, indicating an important role of other electron acceptors (e.g. nitrate) (Koho \& Piña-Ochoa 2012). On the eutrophic side of the model, redox zonation determines the maximum sediment depth that most species can inhabit. In this environment, physiological (Risgaard-Petersen et al. 2006, PiñaOchoa et al. 2010), cellular (Bernhard \& Bowser 2008, Bernhard et al. 2012) and symbiotic adaptations (Bernhard 2003, Bernhard et al. 2006) permit some species to overcome the hostile geochemical conditions. As stated earlier, several studies have described the benthic foraminiferal community in oxygendeficient environments (e.g. in OMZs), mainly in response to the bottom water oxygenation and/or the sedimentary organic carbon contents. However, the relationship between benthic foraminifera and OM quality and redox conditions in oxygen-deficient sediments has not been well documented.

OMZs are marine regions of permanent oxygen stress mainly localized in eastern boundary upwelling systems (Helly \& Levin 2004). OMZs are recognized sources of greenhouse gases such as $\mathrm{NO}_{2}$ and $\mathrm{CO}_{2}$ (Paulmier et al. 2011, Franco et al. 2014) and have been globally expanding in volume in the last decades (Stramma et al. 2008). The sediments underneath an OMZ present strong biogeochemical gradients that directly affect benthic communities (Levin 2003). In these oxygen-deficient settings, intense OM re-mineralization can lead to oxygen depletion and the use of a sequence of other electron acceptors in OM oxidation mediated by microorganisms (Froelich et al. 1979), with sulfate reduction appearing as the dominant biogeochemical process (Middelburg \& Levin 2009, Levin et al. 2009). Different microenvironments in the surface sediments can then be displayed, which can be associated with the presence of free sulfide and/or the depth of the sulfidic layer in the sediment. Bernhard \& Sen Gupta (1999) utilized 2 terms for environments with no detectable oxygen: 'anoxic', referring to a condition devoid of oxygen, and 'postoxic', as a subclass of anoxic in which there is lack of both oxygen and reducing conditions. Likewise, for a proper description of the natural environment, Canfield \& Thamdrup (2009) proposed a vocabulary in association with the geochemistry and the metabolic processes involved. Because of the relevance of sulfate reduction in OMZ sediments, in this article we use the terms 'sulfidic' in reference to conditions devoid of oxygen (anoxic) and with high values of free sulfide in the pore water, and 'postoxic' when referring to anoxic conditions in which sulfide is not detected or is at very low levels.

In this study, we investigated the surface sediments of the upper continental margin off Callao and Pisco in central Peru. Strong, year-round upwelling occurs in this area, resulting in high primary productivity rates (3 to $4 \mathrm{~g} \mathrm{C} \mathrm{m}^{-2} \mathrm{~d}^{-1}$ ) (Pennington et al. 2006, Chavez \& Messié 2009). The settling and sedimentary OM generates a high respiratory demand, especially near the coast, which amplifies the intensity of the OMZ (Gutiérrez et al. 2008). Anoxic and sulfidic conditions prevail in the central Peruvian inner shelf sediments under the 'neutral' and cool phases of the El Niño Southern Oscillation (ENSO). Development and senescence of algal blooms following enhanced thermal stratification play an important role in the origin of fluffy sulfidic layers in the sediment during austral summer and autumn (Gutiérrez et al. 2008). However, subsurface oxygenation in the study area is promoted by the poleward propagation of coastal trapped waves, which deepen the oxycline and have a greater impact during ENSO warm phase periods (Gutiérrez et al. 2008).

Off central Peru, Mallon (2012) described a zonation of benthic foraminifera in relation to bottom water oxygen across and below the OMZ. Cardich et al. (2012) identified 2 different communities of benthic foraminifera in the shelf off Callao, and indicated their association with the availability of labile $\mathrm{OM}$ and the presence and concentration of pore water sulfide. Moreover, records of benthic foraminifera $(>125 \mu \mathrm{m})$ over the last $200 \mathrm{yr}$ off Pisco $\left(14^{\circ} \mathrm{S}\right)$ have shown variations in the patterns of dominant species (Morales et al. 2006) that can be related to sediment redox changes because of climate variability (Gutiérrez et al. 2009).

We aimed to determine the controlling factors in the distribution of benthic foraminifera under oxygen deficiency and/or depletion, and to determine the 
composition of species assemblages that could be used as indicators of reducing geochemical conditions. We focused on calcareous taxa because of their relevance to paleo-environmental investigations. We hypothesized that in the sediments below oxygendeficient bottom waters off central Peru, labile OM and pore water redox control the diversity of the community and the microhabitat of the dominant species, respectively.

\section{MATERIALS AND METHODS}

\section{Fieldwork}

Samples were collected as part of the project 'Interaction of the oxygen minimum zone with organic carbon sedimentation and benthic processes (MiniOx)' of the Peruvian Institute of Marine Research (IMARPE). A total of 4 cruises (April and August 2009, April 2010 and April 2011) were conducted along 2 bathymetric transects across the upper continental margin off Callao (12 $\mathrm{S}, 2009$ to 2011) and Pisco (14 ${ }^{\circ} \mathrm{S}_{;} 2010$ to 2011) (Fig. 1), onboard the RVs 'SNP 2' and 'José Olaya Balandra'. The depth of the stations ranged from 48 to $300 \mathrm{~m}$, and they were categorized as inner shelf, middle shelf, outer shelf or upper slope (see Table 1). Hydrographic data (e.g. bottom water dissolved oxygen, BWDO) were collected with a CTD Seabird 19+. Sediment samples were retrieved using a mini multi-corer $(\mathrm{MUC}$, i.d. = $96 \mathrm{~mm}$ ). All undisturbed cores were subsampled immediately after collection. At each station, 2 replicates (from different MUC drops) were taken for benthic foraminifera, $\mathrm{OM}$ and pore water analysis. Only sites with samples of benthic foraminifera were considered for subsequent statistical analyses and discussion in this study (see Tables 1 \& 2 \& Fig. 3 for more data on transects).

\section{Geochemical analyses}

Chlorophyll a (chl a) and phaeopigments (pha) were analyzed fluorometrically in the upper sediment. Cores for phytopigment analyses were sliced each $0.5 \mathrm{~cm}$ for the first $2 \mathrm{~cm}$ and thereafter in a $1 \mathrm{~cm}$ resolution to $10 \mathrm{~cm}$ depth. Samples were stored in aluminum packages, and kept frozen at $-20^{\circ} \mathrm{C}$ until analysis, when they were thawed before extraction. Double extraction with $90 \%$ acetone and fluorescent readings were performed as detailed in Gutiérrez et al. (2000). The sum of chl a and pha contents was termed 'chloroplastic pigment equivalents' (CPE) and used as an indicator of food availability (in $\mathrm{\mu g} \mathrm{g}^{-1}$ ) (Thiel 1978). Following the method of Koho et al. (2008), we calculated the ratio of chl a/pha to assess phytodetritus quality (a measure of labile OM). In addition, from one of the surface replicates at each station, ca. $0.5 \mathrm{~g}$ of wet sediment was set aside for total carbon (TC) and total nitrogen (TN) measurement. Measurements were made in a CNS thermo electron at the laboratory facilities of the Research Unit of the LOCEAN-PALEOPROXUS (IRD) project in Bondy, France. Carbonate contents were measured by ignition in all surface samples from the cruise in April 2011 (Callao and Pisco) and in the sample from Stn P3 in April 2010. Given the range of carbonate measurements (see Table 2), we calculated the mean and coefficient of variation (CV) for inner and middle shelf stations $(13.1 \% ; 0.15)$ and for outer shelf and upper slope stations $(22.7 \%$; 0.14$)$. TC values for all stations during all sampling periods were corrected to estimate total organic carbon (TOC) using the carbonate means, considering a maximum variation of $2 \%(=\mathrm{CV} \times$ $0.12 \times 100$ ) of carbon concentration in the carbonate for both groups of continental margin zones.

The total dissolved sulfide content in pore water, $\Sigma\left(\mathrm{H}_{2} \mathrm{~S}_{1} \mathrm{HS}^{-}, \mathrm{S}^{2-}\right)$, was used as a proxy for redox condition. PVC liners with spirally-arranged holes every $1 \mathrm{~cm}$ were used for pore water sampling. Pore water was extracted from sediment using Rhyzon ${ }^{\circledR}$ capillary samplers connected to syringes. In total, $2 \mathrm{ml}$ of pore water was preserved in vials with $0.5 \mathrm{ml}$ of $5 \%$ zinc acetate and frozen until analyses. Pore water from the 2009 cruises was sampled directly from sliced sedi-

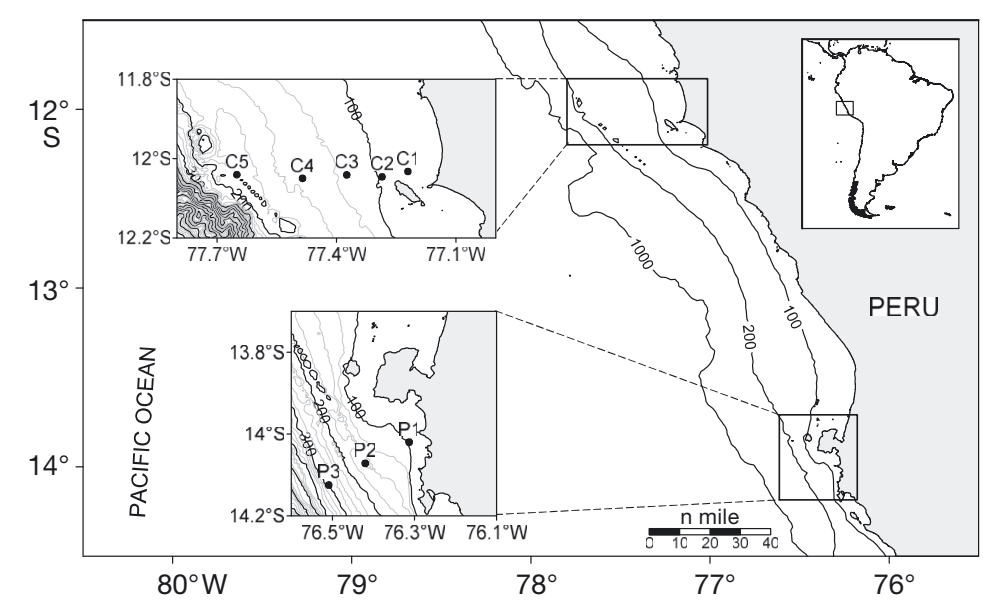

Fig. 1. Continental margin off central Peru. Stations from Callao (C1-C5) and Pisco (P1-P3) are indicated. Contour lines: bathymetry (m); 1 nautical mile $=1.852 \mathrm{~km}$ 
ment in $200 \mathrm{ml}$ plastic tubes with Rhyzon ${ }^{\circledR}$ capillary samplers (Cardich et al. 2012). In the laboratory, $\Sigma \mathrm{H}_{2} \mathrm{~S}$ was determined spectrophotometrically following the method of Cline (1969). Inventories of $\mathrm{\Sigma H}_{2} \mathrm{~S}$ were calculated by correcting pore water concentrations with sediment porosity, and integrating the depth intervals. To distinguish sulfidic from postoxic conditions, we used a threshold pore water $\Sigma \mathrm{H}_{2} \mathrm{~S}$ concentration of $10 \mu \mathrm{mol} \mathrm{kg}{ }^{-1}$, ca. $10 \mu \mathrm{M}=10 \mathrm{nmol} \mathrm{cm}{ }^{-3}$ (Bruland 2006). Given a typical sediment porosity value of $0.9 \mathrm{~cm}^{3}$ pore water $\mathrm{cm}^{-3}$ wet sediment (D. Gutiérrez unpubl. data), the threshold is equivalent to $9 \mathrm{nmol}$ $\mathrm{cm}^{-3}$. Thus at an inventory level, the threshold $(T)$ is calculated as:

$T\left(\mathrm{nmol} \mathrm{cm}{ }^{-2}\right)=Z \times 10 \mathrm{nmol} \mathrm{cm}{ }^{-3} \times 0.9 \mathrm{~cm}^{3} \mathrm{~cm}^{-3} \equiv$ $Z \times 9 \mathrm{nmol} \mathrm{cm}^{-3}$

where $Z$ is the sediment thickness of the inventory.

Inventories for the top $2 \mathrm{~cm}\left(\sum \mathrm{H}_{2} \mathrm{~S}_{[2]}\right)$ were normally used for establishing the redox condition classification. When the $\Sigma \mathrm{H}_{2} \mathrm{~S}_{[2]}$ replicates differed from each other by a factor $\geq 3$, the $\Sigma \mathrm{H}_{2} \mathrm{~S}_{[5]}$ inventories, if available, were used for the calculations.

\section{Benthic foraminifera}

Benthic foraminifera cores were sliced at each $0.5 \mathrm{~cm}$ for the first $2 \mathrm{~cm}$, and then in a $1 \mathrm{~cm}$ resolution to a depth of $5 \mathrm{~cm}$, with the exception of the 2009 samples when all the slices were $1 \mathrm{~cm}$ thick (Cardich et al. 2012). All samples were immediately preserved in plastic jars with $100 \mathrm{ml}$ of $8 \%$ buffered formalin.

In the laboratory, $65 \mathrm{ml}$ of a rose bengal solution ( $1 \mathrm{~g} \mathrm{l}^{-1}$ of $4 \%$ formalin) was added to the samples, which were allowed to stain at least $1 \mathrm{wk}$ before processing. The total volume of each sample was measured and the volumes of all added liquids were subtracted in order to determine the original volume of sediment from each slice (Rathburn \& Corliss 1994). The samples were wet-sieved into $63-150$ or $>150 \mu \mathrm{m}$ size fractions. The $500 \mu \mathrm{m}$ sieve was also used to sort the macrobenthos. The use of the rose bengal staining technique in samples from anoxic sediments has been questioned because the slow decay of protoplasm (Bernhard 2000) complicates the distinction of individuals actually living at the moment of sampling. However, this problem can be minimized by the procedure we followed here when distinguishing between stained and unstained individuals: specimens in which all chambers except for the last one (the youngest), were well-stained were considered 'living' (Tapia et al. 2008, see Rathburn \&
Corliss 1994 for more details), counted in a Petri dish and hand-picked. Additionally, Gooday \& Rathburn (1999) noted that seasonal patterns in foraminiferal assemblages are discernable even in oxygen-poor settings, suggesting that protoplasm decays relatively quickly in deep-sea sediments.

Our results are presented for the $>63 \mu \mathrm{m}$ size fraction of benthic foraminifera in the top $5 \mathrm{~cm}$ of sediment. Even though calcareous foraminifera are the focus of this study, agglutinated and tectinous (e.g. allogromiids) foraminiferal data are reported as well as that of separate groups. Faunal data were normalized to number per $50 \mathrm{~cm}^{3}$ and to number per $50 \mathrm{~cm}^{2}$ for total standing stocks (TSS). Some samples were wet split into manageable volumes (containing ca. 1000 'living' individuals) using a modified Folsom plankton splitter. Species richness $(S$; number of living foraminiferal species), the Shannon-Wiener index $\left(H^{\prime}\right.$; Shannon \& Weaver 1949; a diversity index) and Simpson's index ( $\lambda$; Simpson 1949; a measure of the strength of dominance) were calculated for foraminiferal assemblages in non-normalized samples. The average living depth (ALD) calculated after Jorissen et al. (1995) was used as an indicator of the vertical distribution of species and TSS. In this study, the average living depth for the top $5 \mathrm{~cm}\left(\mathrm{ALD}_{5}\right)$ is reported for the TSS and the most important calcareous species in the area.

\section{Statistical analyses}

A hierarchical cluster analysis (group average) was performed using Primer 6 v.6.1.13 statistical software. Data for the most important calcareous foraminiferal species (where frequency $>4=10 \%$ of the total samples) was used. $Q$-mode and $R$-mode cluster analysis were based on a Bray-Curtis similarity matrix and on non-parametric Spearman correlations, respectively.

Non-parametric Spearman correlation ranks were calculated using Statistica v.10 software to assess the relationship between the environmental parameters with the standing stocks of foraminifera (total, calcareous, agglutinated, tectinous and most important calcareous species) and with $\mathrm{ALD}_{5}$ data. The sample size (n) of the variables varied. For replicated environmental variables, we worked with replicated foraminiferal data as well, whereas for unique measurements (e.g. BWDO, TOC, TN), the average of the foraminiferal replicates was used instead. Further, a multivariate ordination analysis was employed to better explore the relationships and differences in spe- 
cies assemblages with varying environmental states. To fully cover the environmental data, the analysis was held on the non-replicated variables and the averaged values of the replicated variables along with the averaged numbers of foraminifera. Thus, a canonical correspondence analysis (CCA) was performed on the most important calcareous species using the $\mathrm{R}$ statistical environment package v.3.0.1. One particularly attractive feature of the CCA triplot is that species are ordered along the canonical axes following their ecological optima (Borcard et al. 2011). This allows a relatively easy ecological interpretation of species assemblages. Lastly, a non-parametric KruskalWallis ANOVA test was carried with the $\mathrm{ALD}_{5}$ data. This analysis was used to test whether the $\mathrm{ALD}_{5}$ of a given species presented the same distribution among different redox states. Homogenous groups were determined by the Wilcoxon-Mann-Whitney $U$-test. Statistica v.10 was used for this analysis.

For multiple comparisons, the probability level was corrected by dividing the probability level $\alpha$ ( $\mathrm{p}<$ 0.05 ) by the number of tests performed (Glantz 2002).

\section{RESULTS}

\section{Hydrographic characteristics}

BWDO values ranged from 0.03 to $0.38 \mathrm{ml} \mathrm{l}^{-1}$ (Table 1), corresponding to microxic and extreme dysoxic conditions (sensu Bernhard \& Sen Gupta 1999). The highest BWDO concentrations (0.22 to $0.38 \mathrm{ml} \mathrm{l}^{-1}$ ) occurred in the inner and outer shelf during August 2009. These values corresponded to the only winter period in the study, when water column mixing was enhanced by seasonal intensification of winds. Although BWDO values during April 2010 did not differ from the other summer/autumn periods, the dissolved oxygen column profile off Callao and Pisco presented anomalies (Fig. 2b,c). In this period only, following the 2009/2010 El Niño, water column temperature and salinity profiles showed higher values off Callao and Pisco, especially in the inner and middle shelf (data not shown). In the 2010 austral summer there was a deepening of the thermocline and oxycline (to between 70 and $80 \mathrm{~m}$ ) (Fig. 2a)

Table 1. Date, station (C: Callao; P: Pisco), geographical position, water depth, distance to coast line (DC), geographical zone and bottom water oceanographic factors of sampling sites. IS: inner shelf; MS: middle shelf; OS: outer shelf; US: upper slope; n mile: nautical mile; BWDO: bottom-water dissolved oxygen

\begin{tabular}{|c|c|c|c|c|c|c|c|c|c|c|}
\hline Cruise & $\begin{array}{c}\text { Date } \\
\text { (mm/dd/yyyy) }\end{array}$ & Station & $\begin{array}{l}\text { Latitude } \\
\text { (S) }\end{array}$ & $\begin{array}{l}\text { Longitude } \\
\text { (W) }\end{array}$ & $\begin{array}{l}\text { Depth } \\
\text { (m) }\end{array}$ & $\begin{array}{c}\mathrm{DC} \\
\text { (n mile) }\end{array}$ & Zone & $\begin{array}{c}\text { Temperature } \\
\left({ }^{\circ} \mathrm{C}\right)\end{array}$ & Salinity & $\begin{array}{l}\text { BWDO } \\
\left(\mathrm{ml} \mathrm{l}^{-1}\right)\end{array}$ \\
\hline CRIO & \multirow[t]{5}{*}{ 04/19/2009 } & $\mathrm{C} 1$ & $12^{\circ} 01.90$ & $77^{\circ} 13.07$ & 48 & 3 & IS & 14.8 & 34.98 & 0.15 \\
\hline \multirow[t]{4}{*}{0904} & & $\mathrm{C} 2$ & $12^{\circ} 02.76$ & $77^{\circ} 17.27$ & 94 & 8 & IS & 14.6 & 34.98 & 0.11 \\
\hline & & C3 & $12^{\circ} 02.34$ & $77^{\circ} 22.53$ & 117 & 13 & MS & 14.4 & 34.97 & 0.11 \\
\hline & & $\mathrm{C} 4$ & $12^{\circ} 02.93$ & $77^{\circ} 29.01$ & 143 & 20 & OS & 14.0 & 34.96 & 0.19 \\
\hline & & C5 & $12^{\circ} 02.22$ & $77^{\circ} 39.07$ & 175 & 30 & OS & 13.6 & 34.94 & 0.13 \\
\hline MiniOx & \multirow[t]{4}{*}{ 08/20/2009 } & $\mathrm{C} 1$ & $12^{\circ} 01.90$ & $77^{\circ} 13.07$ & 48 & 3 & IS & 15.2 & 35.00 & 0.38 \\
\hline \multirow[t]{3}{*}{0908} & & $\mathrm{C} 2$ & $12^{\circ} 02.76$ & $77^{\circ} 17.27$ & 94 & 8 & IS & 14.6 & 34.98 & 0.24 \\
\hline & & $\mathrm{C} 4$ & $12^{\circ} 02.93$ & $77^{\circ} 29.01$ & 143 & 20 & OS & 13.9 & 34.96 & 0.22 \\
\hline & & C5 & $12^{\circ} 02.22$ & $77^{\circ} 39.07$ & 175 & 30 & OS & 13.1 & 34.91 & 0.19 \\
\hline CRIO & \multirow[t]{5}{*}{$04 / 27 / 2010$} & $\mathrm{C} 1$ & $12^{\circ} 01.90$ & $77^{\circ} 13.07$ & 48 & 3 & IS & 16.7 & 35.07 & 0.28 \\
\hline \multirow[t]{7}{*}{1004} & & $\mathrm{C} 2$ & $12^{\circ} 02.76$ & $77^{\circ} 17.27$ & 94 & 8 & IS & 16.4 & 35.07 & 0.13 \\
\hline & & C3 & $12^{\circ} 02.34$ & $77^{\circ} 22.53$ & 117 & 13 & MS & 15.8 & 35.06 & 0.12 \\
\hline & & $\mathrm{C} 4$ & $12^{\circ} 02.93$ & $77^{\circ} 29.01$ & 143 & 20 & OS & 15.0 & 35.10 & 0.09 \\
\hline & & C5 & $12^{\circ} 02.22$ & $77^{\circ} 39.07$ & 175 & 30 & OS & 14.3 & 35.00 & 0.18 \\
\hline & \multirow[t]{3}{*}{ 04/29/2010 } & $\mathrm{P} 1$ & $14^{\circ} 01.20$ & $76^{\circ} 18.78$ & 120 & 5 & MS & 14.8 & 35.01 & 0.07 \\
\hline & & $\mathrm{P} 2$ & $14^{\circ} 04.32$ & $76^{\circ} 25.20$ & 180 & 11 & OS & 14.5 & 35.01 & 0.04 \\
\hline & & P3 & $14^{\circ} 07.50$ & $76^{\circ} 30.54$ & 300 & 14 & US & 11.2 & 34.80 & 0.04 \\
\hline CRIO & \multirow[t]{8}{*}{ 04/20/2011 } & $\mathrm{C} 1$ & $12^{\circ} 01.90$ & $77^{\circ} 13.07$ & 48 & 3 & IS & 15.7 & 34.99 & 0.08 \\
\hline \multirow[t]{7}{*}{1104} & & $\mathrm{C} 2$ & $12^{\circ} 02.76$ & $77^{\circ} 17.27$ & 94 & 8 & IS & 15.5 & 34.99 & 0.04 \\
\hline & & $C 3^{\mathrm{a}}$ & $12^{\circ} 02.34$ & $77^{\circ} 22.53$ & 117 & 13 & MS & 15.1 & 34.99 & 0.09 \\
\hline & & $\mathrm{C} 4^{\mathrm{a}}$ & $12^{\circ} 02.93$ & $77^{\circ} 29.01$ & 143 & 20 & OS & 14.7 & 34.96 & 0.04 \\
\hline & & C5 & $12^{\circ} 02.22$ & $77^{\circ} 39.07$ & 175 & 30 & OS & 15.1 & 34.99 & 0.09 \\
\hline & & $\mathrm{P} 1^{\mathrm{a}}$ & $14^{\circ} 01.20$ & $76^{\circ} 18.78$ & 120 & 5 & MS & 14.4 & 34.98 & 0.05 \\
\hline & & P2 & $14^{\circ} 04.32$ & $76^{\circ} 25.20$ & 180 & 11 & OS & 14.7 & 34.96 & 0.04 \\
\hline & & $\mathrm{P} 3^{\mathrm{b}}$ & $14^{\circ} 07.50$ & $76^{\circ} 30.54$ & 300 & 14 & US & 14.7 & 34.99 & 0.03 \\
\hline
\end{tabular}


a
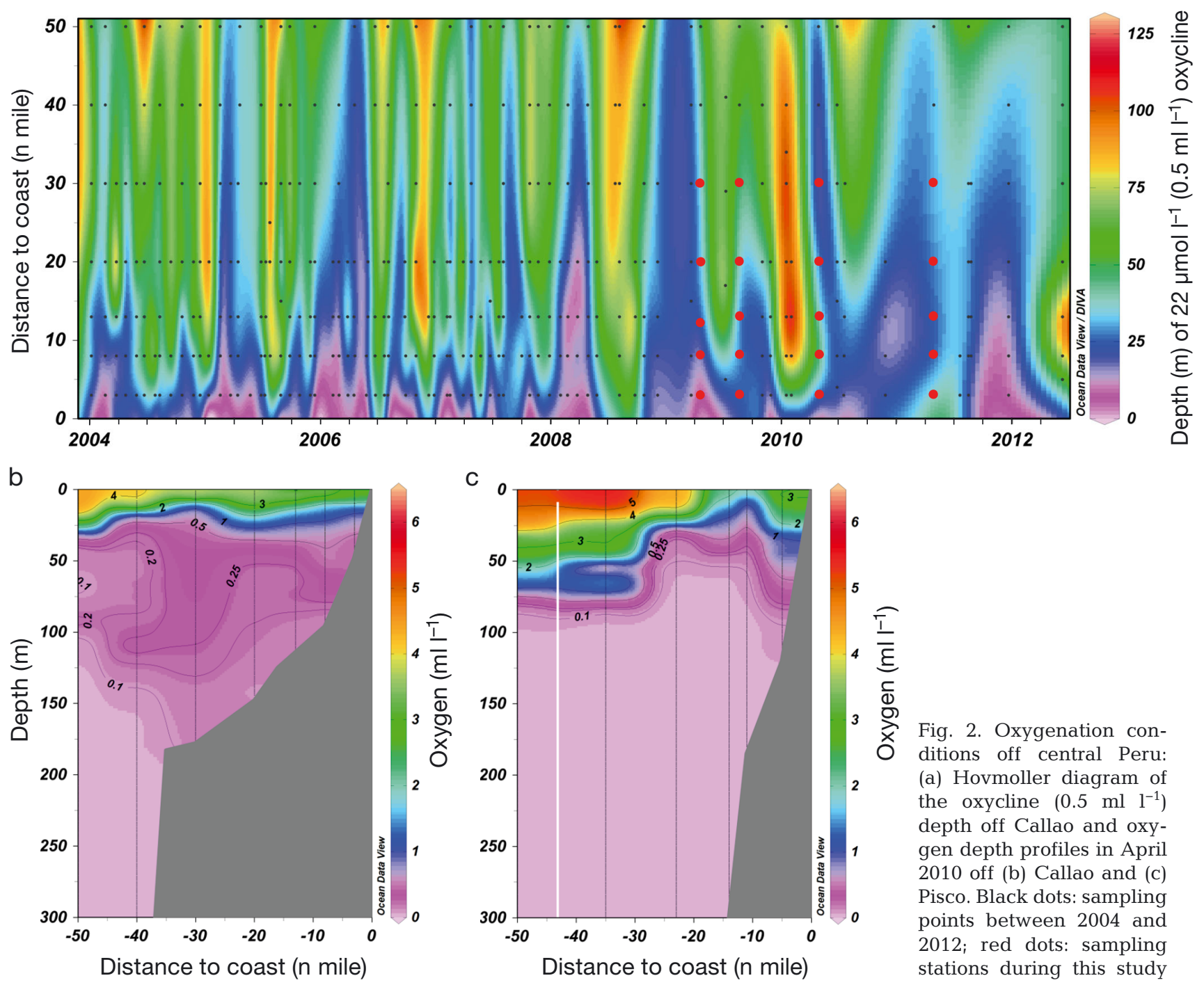

Fig. 2. Oxygenation conditions off central Peru: (a) Hovmoller diagram of the oxycline $\left(0.5 \mathrm{ml} \mathrm{l}^{-1}\right)$ depth off Callao and oxygen depth profiles in April 2010 off (b) Callao and (c) Pisco. Black dots: sampling points between 2004 and 2012; red dots: sampling stations during this study

driven by the intrusion of superficial subtropical waters over the 20 nautical miles ( $\mathrm{n}$ mile) from the coastline (Gutiérrez et al. 2010).

\section{Geochemical factors in the upper sediment}

\section{Bulk OM}

TOC and TN values ranged from 3.1 to $12.2 \%$ and from 0.5 to $1.8 \%$, respectively (Table 2 ). Both distributions were strongly correlated (see Table 4), showing an increase towards the shelf-break and upper slope in all sampling periods. The largest range of values for both TOC and TN occurred in April 2010. The lowest values of TOC $(1.8 \%)$ and TN $(0.4 \%)$ were found in the shallowest station off Callao (Stn
C1), whereas the deepest Callao station (Stn C5) exhibited the highest values ( $\mathrm{TOC}=12.2 \%, \mathrm{TN}=1.8 \%$ ).

\section{Phytopigments}

CPE content in the first centimetre of sediment presented a general increase with water depth (Table 2). Its distribution did not show the same marked trends with depth as TOC and TN however, exhibiting local peaks during some sampling periods. CPE content in inner shelf stations ranged from 73.0 to $827.2 \mu \mathrm{g} \mathrm{g}^{-1}$, with one replicate showing a high value of $2145.2 \mu \mathrm{g}$ $\mathrm{g}^{-1}$ at Stn C2 in April 2010 (Table 2). Values from the deeper (middle and outer shelf and upper slope) stations ranged from 302.0 to $1514.8 \mu \mathrm{g} \mathrm{g}^{-1}$. However, values $<300 \mu \mathrm{g} \mathrm{g}^{-1}$ were recorded from some repli- 
Table 2. Main sedimentary parameters in the top centimetre and pore water sulfide inventories $\left(\mu \mathrm{mol} \mathrm{cm} \mathrm{cm}^{-2}\right)$ for the first $2\left(\Sigma \mathrm{H}_{2} \mathrm{~S}_{[2]}\right)$ and 5 $\left(\Sigma \mathrm{H}_{2} \mathrm{~S}_{[5]}\right) \mathrm{cm}$ of sampling sites during all sampling periods. Additional data regarding organic matter quality (e.g. microbial carbon to total organic carbon ratio [Bact-C/TOC]) is shown for some periods. R: replicate; CPE: chloroplastic pigment equivalents; chl a/pha: ratio of chlorophyll a to phaeopigments; TC: total carbon; TOC: total organic carbon calculated by the difference between $\mathrm{TC}(\%)$ and $\mathrm{CaCO} 3$ (\%) (see 'Materials and methods: geochemical analyses' for details); TN: total nitrogen; $\Sigma \mathrm{H}_{2} \mathrm{~S}$ : inventory of pore water free sulfides. Redox states: S: sulfidic; P: postoxic; M: mixed. nd: no data

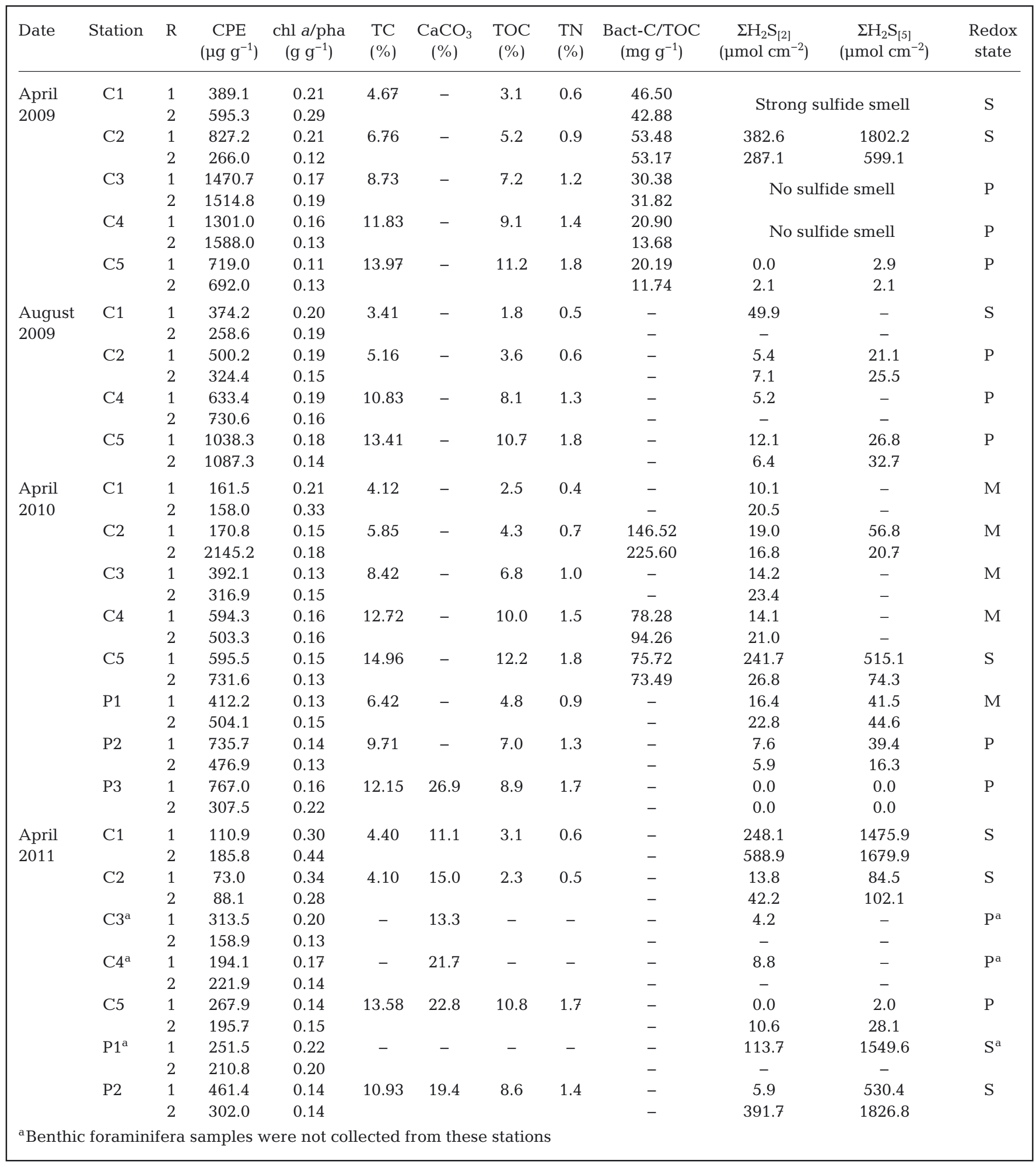


cates during the last sampling period (Table 2). It was also noted that the tendency for CPE to increase with water depth was weaker during the summer of 2010 and 2011 than in both 2009 sampling periods (Table 2).

Contrary to the CPE contents, the chl a/pha ratio in the topmost sediment presented a decrease with water depth (Table 2); thus, this ratio was negatively correlated to TOC and TN contents (see Table 4). $\mathrm{Chl} \mathrm{a} / \mathrm{ph}$ a ratio values in the inner shelf sediments ranged from 0.12 to $0.44 \mathrm{~g} \mathrm{~g}^{-1}$ (Table 2). Only during August 2009 did values not surpass $0.20 \mathrm{~g} \mathrm{~g}^{-1}$ in these sediments (Table 2). The next summer (April 2010), the chl a/pha ratio was relatively higher, but only in the shallowest station off Callao (Stn C1). The highest ratios were recorded in the following period (April 2011), with values $>0.28 \mathrm{~g} \mathrm{~g}^{-1}$ (Table 2). Conversely, lower chl a/pha ratios were recorded in the deeper sites, fluctuating between 0.13 and $0.22 \mathrm{~g} \mathrm{~g}^{-1}$ (Table 2). Stn C2 appeared to be a transition between inner shelf and deeper sites, as both high and low ratio values were found there during different periods.

Downcore profiles of CPE and chl a/pha ratios in the study area exhibited distinct tendencies in relation to distance from the coast (Fig. 3a). In the inner shelf, the topmost sediment generally exhibited high CPE contents $\left(>75 \mu \mathrm{g} \mathrm{cm}^{-3}\right)$, decreasing downcore. The $\mathrm{chl}$ a/pha ratio in the inner shelf also decreased downcore from very high values in the topmost sediment. Conversely, profiles in the middle and outer shelf and upper slope sediments were more pronounced for CPE and relatively uniform downcore for the chl a/ pha ratio (Fig. 3b). During April 2010, the typical profiles dominated, but the trend at inner shelf Stn C2 was not as evident as during the other summer/autumn periods. The profiles from all stations during August 2009 displayed a similar homogenous trend downcore.

\section{Pore water sulfide and redox conditions}

The inventories $\left(\mathrm{nmol} \mathrm{cm}^{-2}\right)$ of pore water sulfide in the first $2\left(\Sigma \mathrm{H}_{2} \mathrm{~S}_{[2]}\right)$ and $5\left(\Sigma \mathrm{H}_{2} \mathrm{~S}_{[5]}\right) \mathrm{cm}$ of sediment were calculated for all stations (Table 2). Typically, sulfide contents were notably high in the inner shelf stations and showed a steep drop towards deeper sites (Table 2). Sulfide was not measured at all sta-
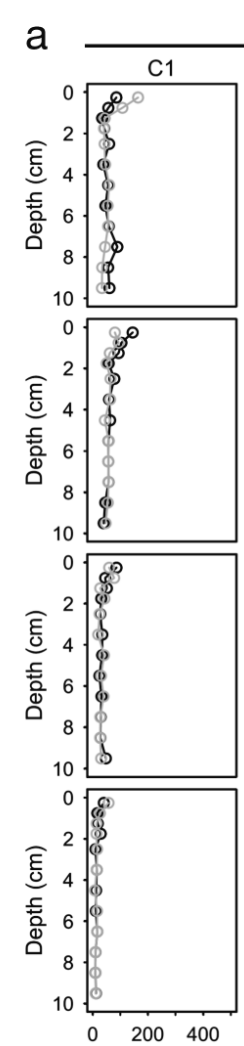
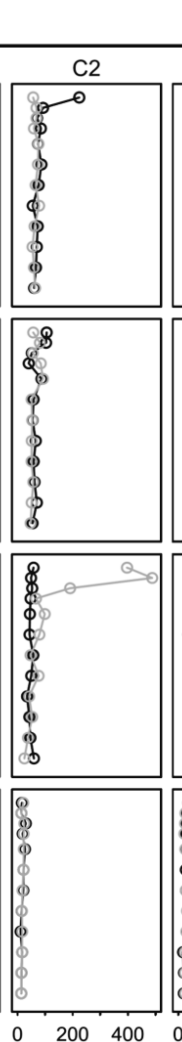

CALLAO
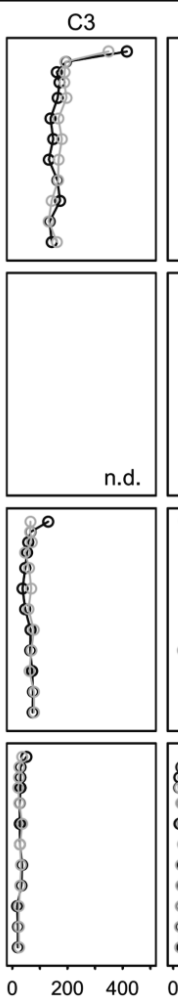
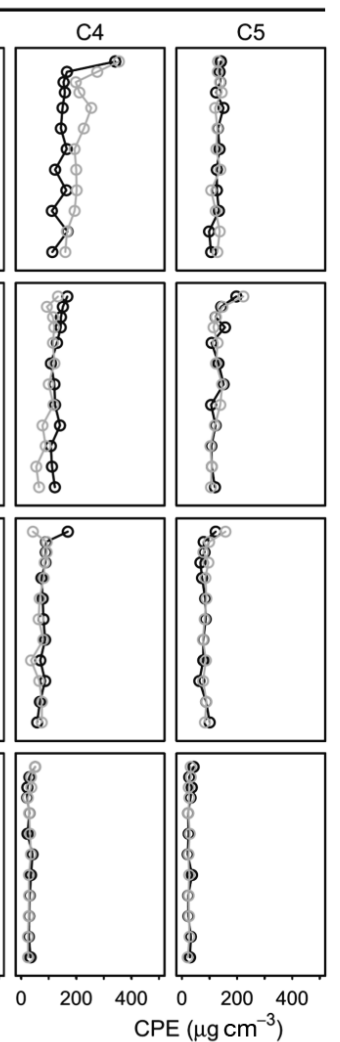
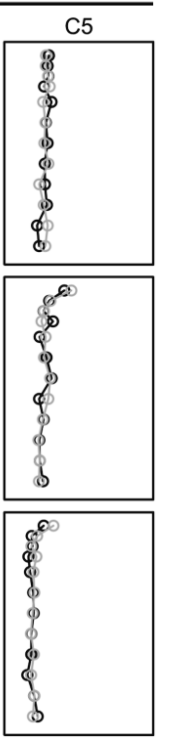

$\mathrm{E}\left(\mu \mathrm{g} \mathrm{cm}^{-3}\right)$

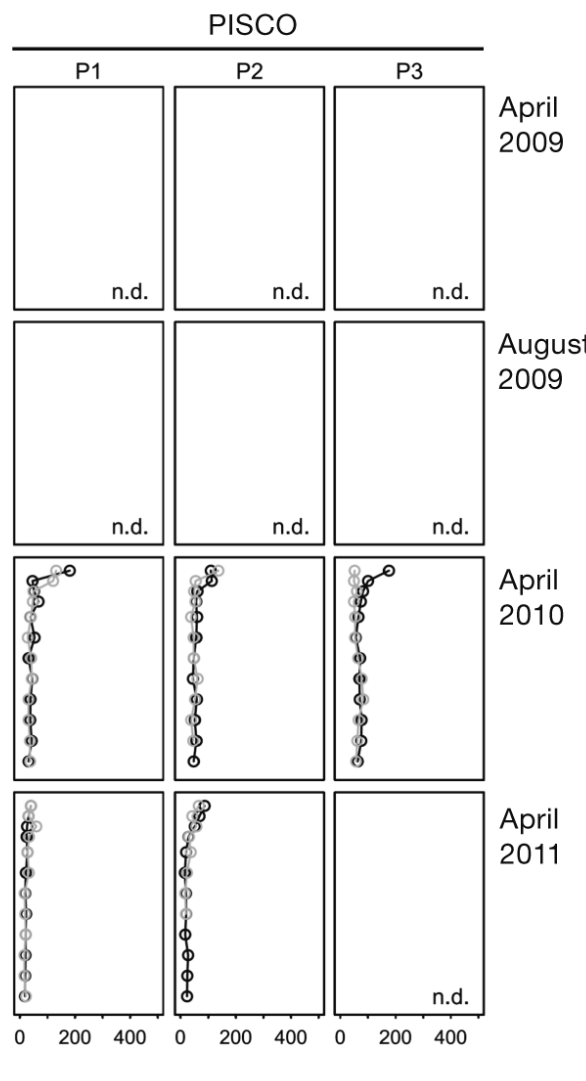

Fig. 3 (continued on next page). Downcore profiles (both replicates) at all sampling sites for (a) chloroplastic pigment equivalents (CPE), (b) ratio of chlorophyll a to phaeopigments (chl a/pha) and (c) pore water sulfide $\left(\mathrm{H}_{2} \mathrm{~S}\right)$. At each station, black and gray dots and lines represent replicates 1 and 2, respectively; nd: no data 

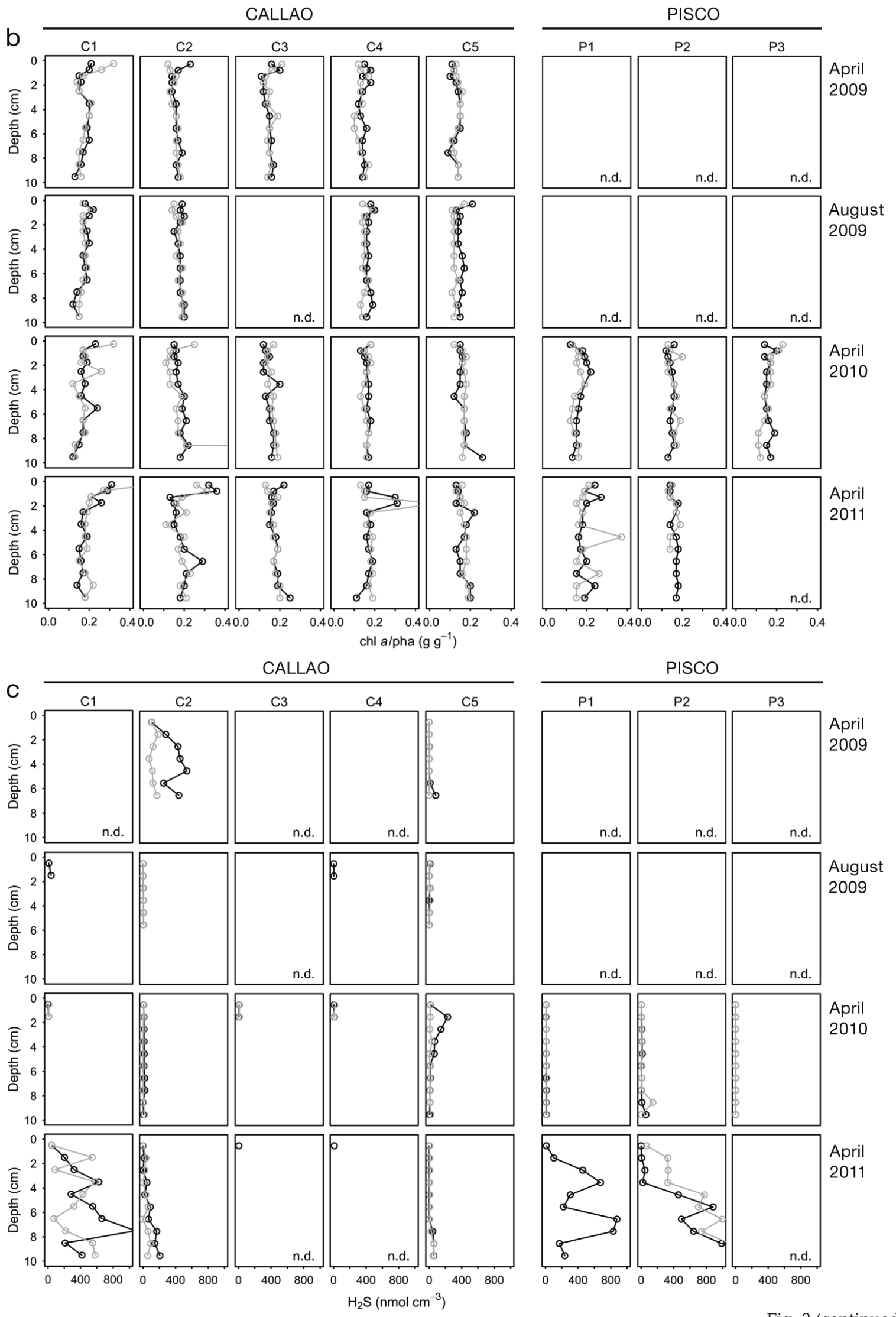

Fig. 3 (continued) 
tions in April 2009; nevertheless, in the shallowest Callao station (Stn C1) a strong sulfide smell emanating from the sediment was noticed in the multicore liners. This was not the case for the deeper stations (Stns C3 and C4) (Cardich et al. 2012). During April $2010, \Sigma \mathrm{H}_{2} \mathrm{~S}_{[2]}$ values were homogenous across the Callao shelf, with the exception of a high record $\left(241.7 \mathrm{nmol} \mathrm{cm}^{-2}\right)$ in one replicate at Stn C5 (Table 2). Off Pisco, $\Sigma \mathrm{H}_{2} \mathrm{~S}_{[2]}$ values clearly decreased with water depth in April 2010, but increased in 2011 (Table 2). Despite not having a complete set of $\mathrm{\Sigma H}_{2} \mathrm{~S}_{[5]}$ inventories, we consider the $\Sigma \mathrm{H}_{2} \mathrm{~S}_{[2]}$ data to be sufficiently complete and representative for this study since both $\Sigma \mathrm{H}_{2} \mathrm{~S}_{[2]}$ and $\Sigma \mathrm{H}_{2} \mathrm{~S}_{[5]}$ inventories were strongly correlated (Spearman's $\rho=0.86, \mathrm{p}<0.05$ ).

Downcore profiles for sulfide are shown in Fig. 3c. Inner shelf sediments exhibited a rapid increment of sulfide (1 order of magnitude in some cases) in the second centimetre. In contrast, sediments at the deeper shelf and upper slope sites presented a common trend of low ( $\left.<15 \mathrm{nmol} \mathrm{cm}^{-3}\right)$ and uniform values downcore. The only station devoid of detectable sulfide at all sediment intervals was upper slope Stn P3 off Pisco in April 2010.

The discrimination criterion for redox conditions was applied for the topmost $2 \mathrm{~cm}$, as this layer represents the interval where the majority of the benthic foraminiferal community concentrates (see below). Although oxygen was not measured in the pore water, given the organic-rich conditions of these upper margin sediments and the strong dysoxia of the bottom waters, we assumed that the free oxygen was consumed completely in the top few millimetres of sediment. Thus, we used the $\Sigma \mathrm{H}_{2} \mathrm{~S}_{[2]}$ inventories to distinguish the redox conditions. Applying Eq. (1), the boundary between the sulfidic state and postoxia corresponded to

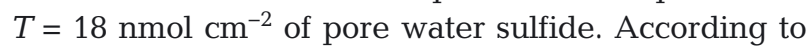
this, the inner shelf stations off Callao were always sulfidic, with the exception of the $94 \mathrm{~m}$ depth station off Callao (Stn C2) in August 2009 (Table 2). In contrast, postoxic conditions were encountered at the deeper stations, with the sulfide-free upper slope station off Pisco (Stn P3) representing the postoxic extreme. It should be noted that some stations exhibited mixed or borderline conditions between a sulfidic condition and postoxia, since $\Sigma \mathrm{H}_{2} \mathrm{~S}_{[2]}$ average values were not significantly different $( \pm 1$ SD) from the threshold value. Thus, the majority of the shelf stations off Callao (Stns C1 to C4) and the Pisco Stn P1 during April 2010 were considered to be under a 'mixed' condition. Conversely, Stns C2 and P2 (during April 2011) and C5 (April 2010), all with very different replicate values, were positioned under the sulfidic condition (Table 2).
These patterns are summarized in Fig. 4. By integrating the spatial and temporal scales of all samples, we recreated a redox gradient based on the $\Sigma \mathrm{H}_{2} \mathrm{~S}_{[2]}$ inventories. The sulfidic, postoxic and 'mixed' conditions can be outlined in the gradient. The distribution of the other sedimentary variables and the BWDO can be visualized in relation to this gradient.

\section{Benthic foraminiferal community}

TSS and calcareous foraminiferal diversity

In general, benthic foraminiferal TSS exhibited mean values $>3500$ ind. $50 \mathrm{~cm}^{-2}$ at all stations (Table 3). Off Callao, TSS did not vary greatly among sites, but showed a notable increase with time during the study. Off Pisco, an increase in TSS with water depth was observed in April 2010. Calcareous foraminifera largely dominated the community ( $>71 \%$ of TSS); tectinous foraminiferal densities typically increased onshore, while agglutinated foraminifera increased offshore.

A total of 43 taxa were identified off Callao and Pisco, composed of 30 calcareous taxa, 8 agglutinated taxa and 5 allogromiid morphotypes (Table 3). Diversity parameters of calcareous foraminifera differed among stations, and species richness $\left(S_{\mathrm{C}}\right)$ increased with water depth (Table 3 ). $S_{\mathrm{C}}$ at the inner shelf stations did not surpass 14 species while in the outer shelf/slope $S_{\mathrm{C}}$ was generally greater than 15 species. During April 2010, $S_{\mathrm{C}}$ was only 5 or 6 species at all stations off Callao. Shannon's $H_{\mathrm{C}}^{\prime}$ was normally higher with depth off Callao, displaying negative correlations with the chl a/pha ratio and $\Sigma \mathrm{H}_{2} \mathrm{~S}_{[2]}$ (Table 4). Dominance $\left(\lambda_{\mathrm{C}}\right)$ showed the opposite trends of $H_{\mathrm{C}}^{\prime}$ and incremented with the chl a/pha ratio. From the calcareous composition at each station, only 5 species (Bolivina seminuda, B. costata, Buliminella tenuata, Nonionella auris and Bolivina pacifica) represented more than $5 \%$ of TSS (Table 3). See Table A1 in the Appendix for the taxonomic references of these species.

\section{Cluster analysis}

Foraminiferal data used in the cluster analysis ( $Q$ and $R$-mode) corresponded to the 18 most frequent ( $>4$ occurrences) calcareous species (Table 3 ). Cancris sp. and Buliminella curta were not considered in the analysis because of their low abundances (>0.1\%). From the $Q$-mode cluster analysis (42 samples), 3 main groups of stations were formed (Fig. 5a). Cluster I corresponded only to samples of the shallowest sta- 


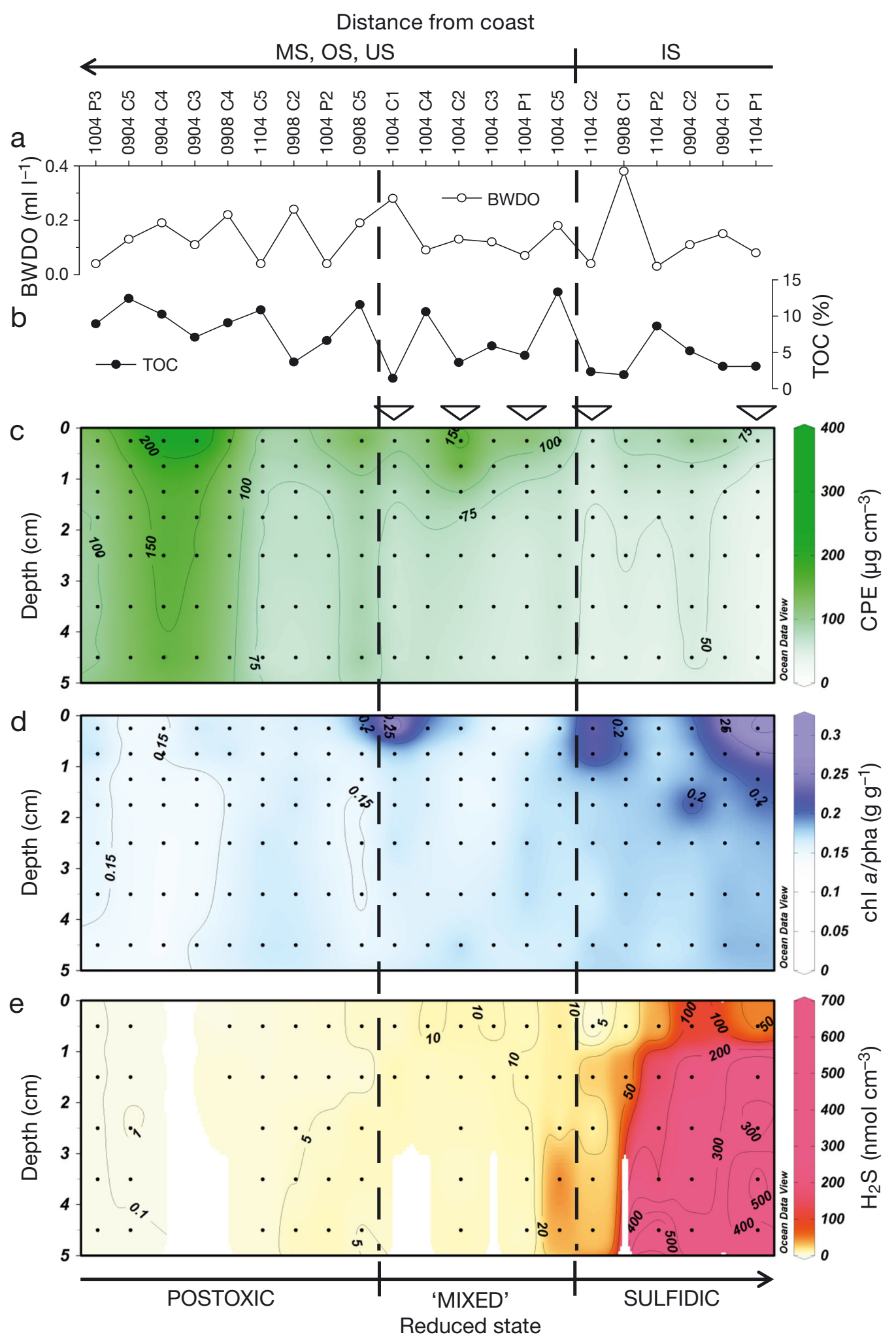

Fig. 4. Geochemical conditions along a fixed redox gradient. (a) Bottom-water dissolved oxygen (BWDO), (b) surface total organic carbon (TOC), and vertical profiles $(0$ to $5 \mathrm{~cm}$ ) of (c) chloroplastic pigment equivalents (CPE), (d) ratio of chlorophyll a to phaeopigments (chl a/pha) and (e) pore water sulfide $\left(\mathrm{H}_{2} \mathrm{~S}\right.$ ) along the increasing $\mathrm{L}_{2} \mathrm{~S}_{[2]}$ gradient. Top horizontal axis in (a) indicates the year, month and station sample. Vertical bars: redox states; triangles: sample sites with Thioploca spp. mats. IS: inner shelf; MS: middle shelf; OS: outer shelf; US: upper slope 


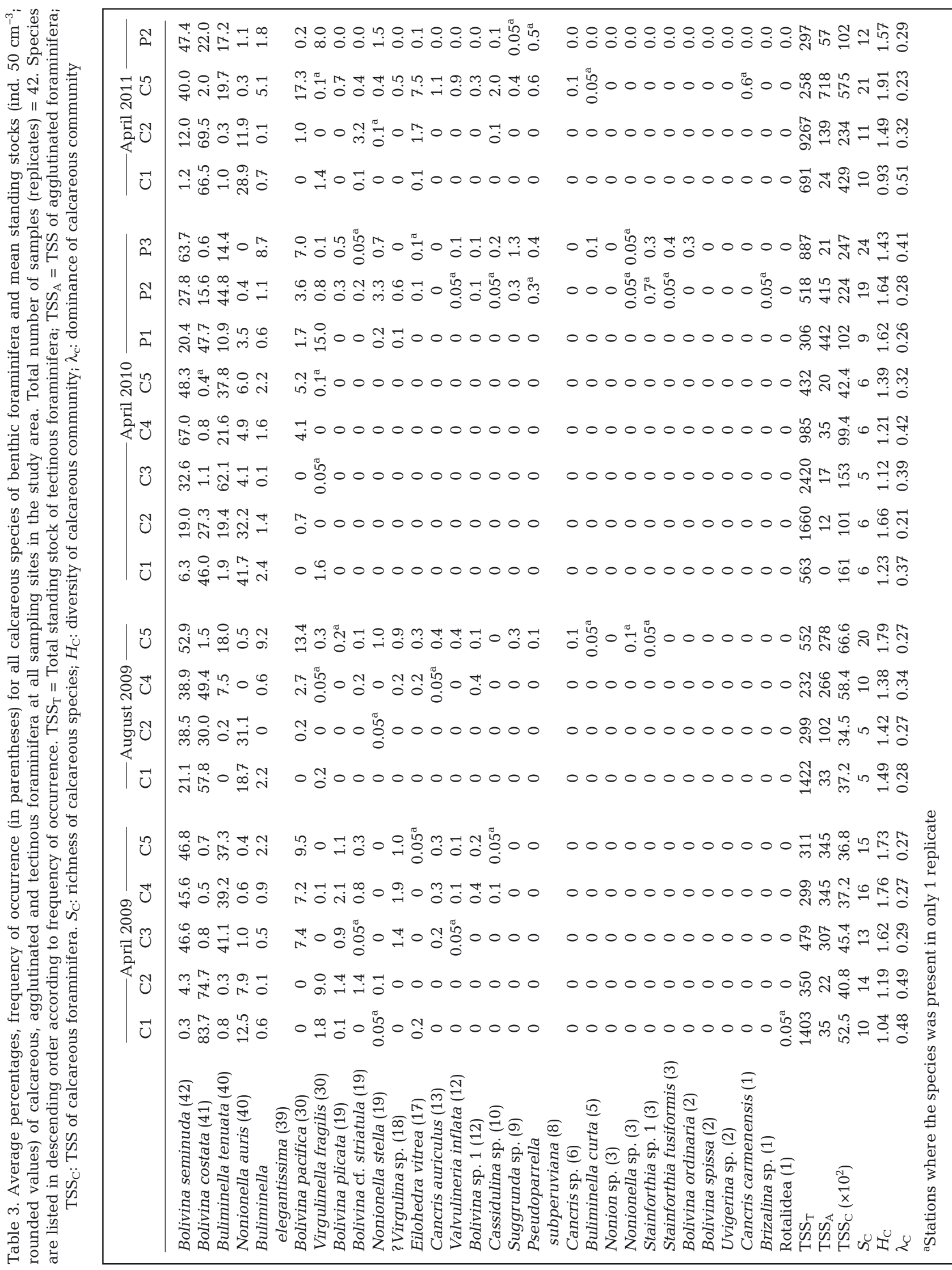


Table 4. Spearman correlation ranks within environmental parameters, and of environmental parameters with the abundances of the benthic foraminiferal ecological groups and the 18 most frequent calcareous species. BWDO: Bottom-water dissolved oxygen; TOC: total organic carbon; TN: total nitrogen; CPE: chloroplastic pigment equivalents; chl a/pha: ratio of chlorophyll a to phaeopigments; $\sum \mathrm{H}_{2} \mathrm{~S}_{[2]}$ : inventory of pore water free sulfides in the top $2 \mathrm{~cm}$ of sediment; Bact-C/TOC: microbial carbon to total organic carbon ratio; TSS: total standing stock of tectinous $\left(\mathrm{TSS}_{\mathrm{T}}\right)$, agglutinated $\left(\mathrm{TSS}_{\mathrm{A}}\right)$ and calcareous $\left(\mathrm{TCC}_{\mathrm{C}}\right.$ ) foraminifera; $S$ : species richness, $H^{\prime}$ : Shannon-Wiener index; $\lambda_{\mathrm{C}}$ : Simpson's index; $S_{\mathrm{C}}, H_{\mathrm{C}}^{\prime} \lambda_{\mathrm{C}}$ : richness, diversity and dominance of calcareous community, respectively. Mean abundances were used for correlations with BWDO, TOC and TN. Significance values after correction for multiple comparisons $(p<0.0015)$

\begin{tabular}{|c|c|c|c|c|c|c|c|}
\hline & $\begin{array}{l}\text { BWDO } \\
(\mathrm{n}=21)\end{array}$ & $\begin{array}{c}\text { TOC } \\
(\mathrm{n}=21)\end{array}$ & $\begin{array}{c}\text { TN } \\
(\mathrm{n}=21)\end{array}$ & $\begin{array}{c}\mathrm{CPE} \\
(\mathrm{n}=42)\end{array}$ & $\begin{array}{c}\mathrm{chl} a / \mathrm{pha} \\
(\mathrm{n}=42)\end{array}$ & $\begin{array}{l}\Sigma \mathrm{H}_{2} \mathrm{~S}_{[2]} \\
(\mathrm{n}=36)\end{array}$ & $\begin{array}{c}\text { Bact-C/TOC } \\
\quad(\mathrm{n}=16)\end{array}$ \\
\hline TOC & - & - & - & - & - & - & - \\
\hline $\mathrm{TN}$ & - & 0.98 & - & - & - & - & - \\
\hline CPE & - & - & - & - & - & - & - \\
\hline chl a/pha & - & -0.61 & -0.62 & - & - & - & - \\
\hline$\Sigma \mathrm{H}_{2} \mathrm{~S}_{[2]}$ & - & - & - & - & - & - & - \\
\hline Bact-C/TOC & - & - & - & - & - & - & - \\
\hline $\mathrm{TSS}_{\mathrm{T}}$ & - & - & - & - & - & - & 0.73 \\
\hline $\mathrm{TSS}_{\mathrm{A}}$ & - & - & - & - & - & -0.60 & -0.96 \\
\hline $\mathrm{TSS}_{\mathrm{C}}$ & -0.63 & - & - & -0.48 & - & - & - \\
\hline Total $S$ & - & - & - & - & - & -0.49 & -0.96 \\
\hline Total $H^{\prime}$ & - & - & - & - & -0.47 & - & - \\
\hline Total $\lambda$ & - & - & - & - & - & - & - \\
\hline$S_{\mathrm{C}}$ & - & - & - & - & - & - & -0.94 \\
\hline$H_{\mathrm{C}}$ & - & - & - & - & -0.49 & -0.48 & - \\
\hline$\lambda_{\mathrm{C}}$ & - & - & - & - & 0.49 & - & - \\
\hline \multicolumn{8}{|l|}{ Assemblage A } \\
\hline Bolivina costata & - & -0.78 & -0.75 & -0.62 & 0.47 & - & - \\
\hline Nonionella auris & - & -0.77 & -0.77 & -0.61 & 0.47 & 0.59 & - \\
\hline Virgulinella fragilis & - & - & - & - & - & - & - \\
\hline \multicolumn{8}{|l|}{ Assemblage B } \\
\hline Bolivina seminuda & - & - & - & - & - & - & - \\
\hline Buliminella tenuata & - & - & 0.59 & - & -0.49 & - & - \\
\hline \multicolumn{8}{|l|}{ Assemblage C } \\
\hline Bolivina pacifica & - & 0.69 & 0.74 & - & - & -0.54 & - \\
\hline Bolivina sp. 1 & - & - & - & - & - & -0.64 & - \\
\hline ? Virgulina sp. & - & - & - & 0.46 & - & -0.56 & -0.80 \\
\hline Cancris auriculus & - & 0.63 & 0.63 & - & - & -0.58 & -0.85 \\
\hline Valvulineria inflata & - & - & 0.61 & - & - & -0.60 & -0.85 \\
\hline \multicolumn{8}{|l|}{ Assemblage D } \\
\hline Cassidulina sp. & -0.60 & - & - & - & - & - & - \\
\hline \multicolumn{8}{|l|}{ Buliminella } \\
\hline elegantissima & - & - & - & - & - & - & - \\
\hline Nonionella stella & -0.68 & - & - & - & - & - & - \\
\hline \multicolumn{8}{|l|}{ Pseudoparrella } \\
\hline subperuviana & - & - & - & - & - & -0.54 & - \\
\hline Suggrunda eckisi & - & - & - & - & - & -0.56 & - \\
\hline \multicolumn{8}{|l|}{ Assemblage E } \\
\hline Eilohedra vitrea & - & - & - & - & - & - & - \\
\hline Bolivina plicata & - & - & - & - & - & - & -0.77 \\
\hline Bolivina cf. striatula & - & - & - & - & - & - & -0.69 \\
\hline
\end{tabular}

tions off Callao (Stns C1 and C2). The second cluster (II) grouped samples from the middle and outer shelf samples off Callao and Pisco, together with the samples from Stn C2 in April 2010. Lastly, cluster III was formed by samples of the deepest shelf stations (Stns C5 and P2) and the upper slope Stn P3.
Applying a cut-off level of $0.5, R$-mode cluster analysis (18 species) allowed the identification of 5 benthic foraminiferal assemblages and 2 single species (Fig. 5b): assemblage A, composed of Bolivina costata and Nonionella auris; assemblage B, composed of Bolivina seminuda and Buliminella tenuata; 
a

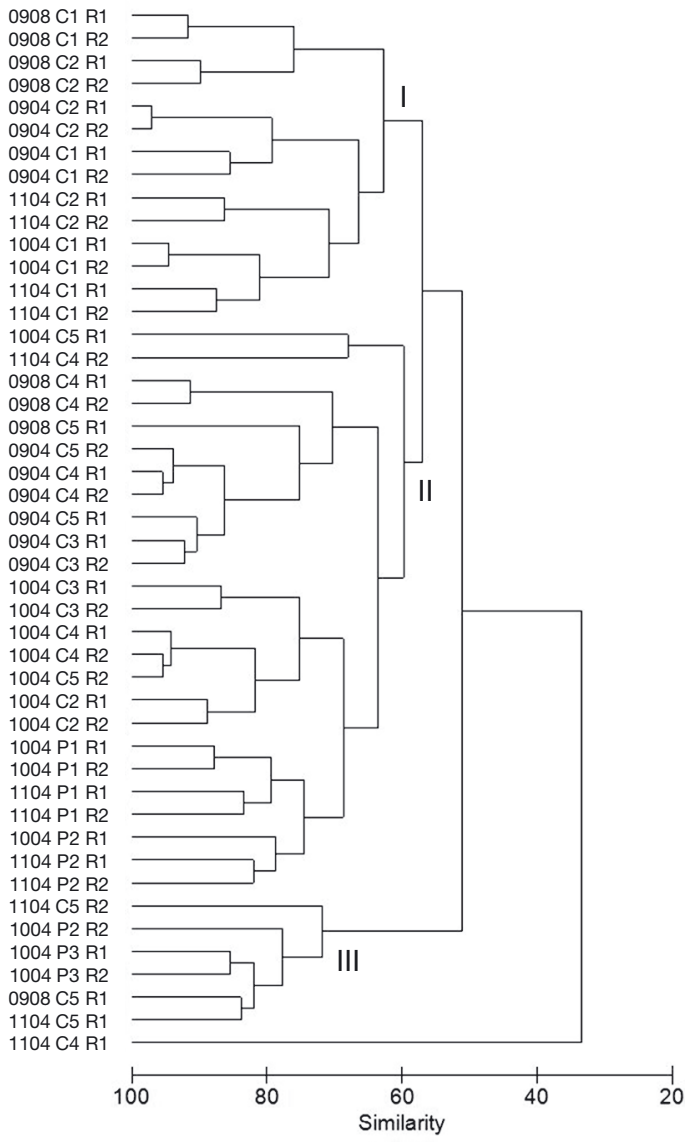

b

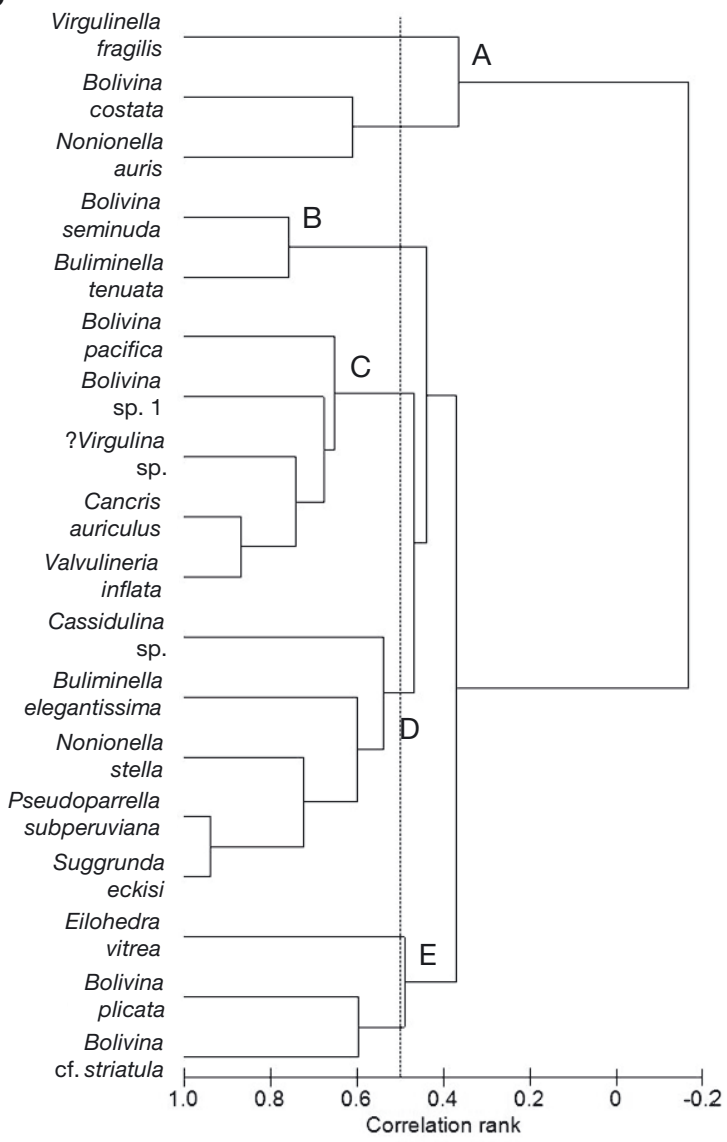

Fig. 5. (a) $Q$-mode and (b) $R$-mode cluster analysis for the replicated data of the abundances of the 18 most frequent calcareous species found in this study. In (a), $y$-axis codes = date (yymm), site and replicate; the labels I-III mark the 3 main goups of stations. In (b), the letters A-E mark the assemblages

assemblage C, with Bolivina pacifica, Bolivina sp. 1, ?Virgulina sp., Cancris auriculus and Valvulineria inflata; assemblage D, with Buliminella elegantissima (see Table A1 in the Appendix), Cassidulina sp., Nonionella stella, Pseudoparrella subperuviana and Suggrunda eckisi; and assemblage E, with Bolivina cf. striatula and Bolivina plicata. The single species Virgulinella fragilis (see Table A1) and Eilohedra vitrea were grouped with assemblages $\mathrm{A}$ and $\mathrm{E}$, respectively, because of their proximity to the cluster.

\section{Distribution of benthic foraminiferal assemblages}

The species comprising assemblage A were abundant at the inner shelf stations off Callao and Pisco and dominated the sulfidic zone (Fig. 6a). Bolivina costata dominated the community at these stations, followed by $N$. auris (Table 3 ), but they were rare at middle and outer shelf and upper slope stations. The densities of both species were significantly correlated with the chl a/pha ratio and $\Sigma \mathrm{H}_{2} \mathrm{~S}_{[2]}$, and were nega- tively correlated with TOC, TN and CPE (Table 4). V. fragilis, with visually lower densities, was only present at the inner shelf stations and did not show significant correlations with any measured parameter.

The species in assemblage B dominated the postoxic sediments (>60\%, Fig. 6a), but were present across the whole gradient ( 0.3 to $47 \%$, Table 3 ). On the Pisco transect in 2010, Bolivina seminuda showed outstanding dominance at the upper slope station, whereas $\mathrm{Bu}$ liminella tenuata peaked at the outer shelf (Table 3). Densities of both species increased in sediments rich in $\mathrm{CPE}$, TOC and TN, and with low values of $\Sigma \mathrm{H}_{2} \mathrm{~S}_{[2]}$ (Fig. 6). Furthermore, only B. tenuata was negatively correlated with the chl a/pha ratio (Table 4).

Assemblage C was restricted to 'mixed' and postoxic sediments (Fig. 6a). Only the largely dominant Bolivina pacifica thrived at sulfidic stations $(<1 \%$, Table 3). B. pacifica showed the same distributional pattern as B. seminuda in the April 2010 transect off Pisco. C. auriculus and V. inflata were common in the outer shelf off Callao, but were only abundant during the April 2011 period. This assemblage in general 
a

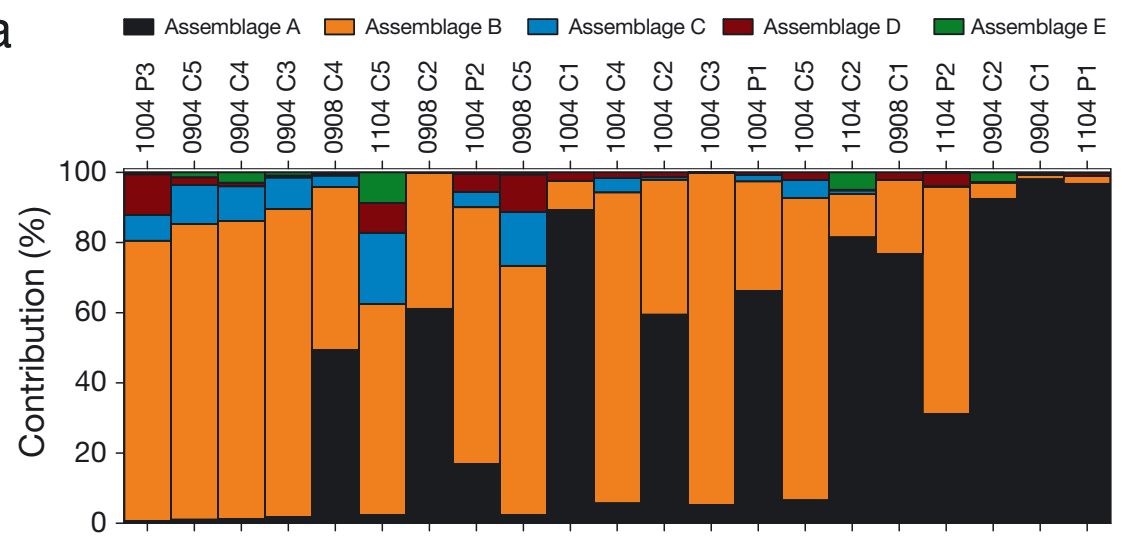

b
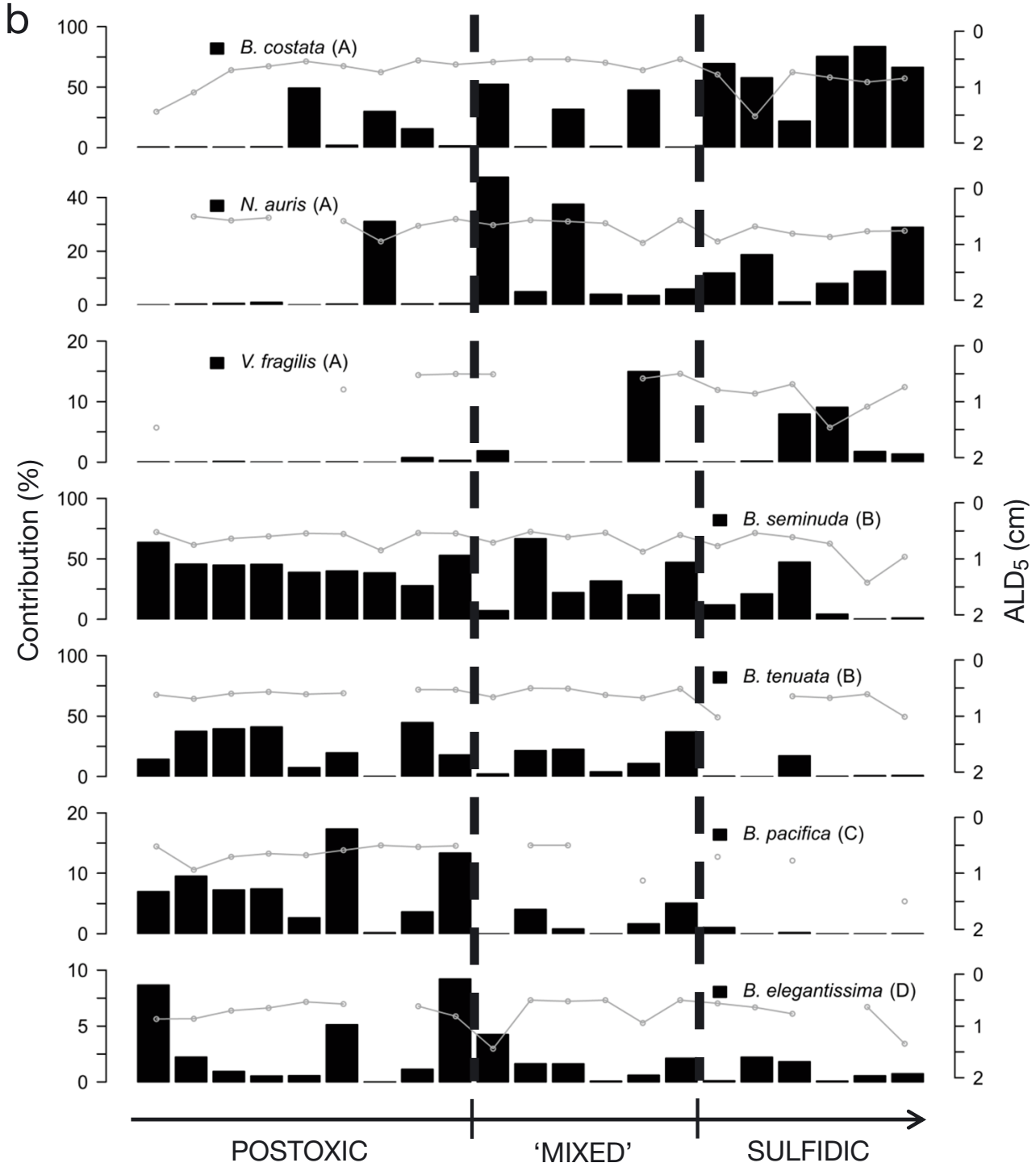

Reduced state

Fig. 6. Relative contribution (\%) to the benthic calcareous foraminiferal community of (a) assemblages and (b) main calcareous species (see Table 4 for full taxonomic names) along the redox gradient. The average living depth for the top $5 \mathrm{~cm}^{(A L D} \mathrm{A}_{5}$ gray lines) of main calcareous species (as-sociated assemblage in brackets) is also shown in (b). Note that the scale on the left vertical axis changes. Codes across the top of (a) are date (yymm) and station 
correlated positively with TOC, TN and $\mathrm{CPE}$, and negatively with $\Sigma \mathrm{H}_{2} \mathrm{~S}_{[2]}$ (Table 4).

Species of assemblages D and E did not show a clear distribution pattern (Fig. 6a), but were rare or absent at inner shelf stations (Table 3). Only Buliminella elegantissima surpassed $0.1 \%$ of TSS in the 2009 and 2010 samples. The other 4 species of assemblage D were more conspicuous off Pisco, but presented notable high abundance peaks off Callao in April 2011 (Table 3). Only P. subperuviana and $S$. eckisi had a significant negative correlation with the chl a/pha ratio and $\Sigma \mathrm{H}_{2} \mathrm{~S}_{[2]}$. Of all calcareous species in the study, only Cassidulina sp. and N. stella were negatively correlated with BWDO (Table 4). Assemblage E species were present across the shelf during different sampling periods (Table 3), but Bolivina plicata and $B$. cf. striatula had a significant negative correlation with the microbial carbon to total organic carbon ratio (Bact-C/TOC; Table 4).

\section{Vertical distribution}

The whole community was concentrated near the sediment-water interface (Fig. 7), with more than $56 \%$ of TSS in the top centimetre of sediment $\left(\mathrm{ALD}_{5}\right.$ values of 0.6 to $1.3 \mathrm{~cm}$ ). $\mathrm{ALD}_{5}$ values of calcareous foraminifera were the same (0.6 to $1.7 \mathrm{~cm})$, whereas agglutinated foraminifera appeared almost exclusively in the topmost sediment $\left(\mathrm{ALD}_{5} \sim 0.5 \mathrm{~cm}\right)$. Vertical distribution of tectinous foraminifera was broader, occurring at deeper sediment intervals $\left(\mathrm{ALD}_{5}=0.6\right.$ to $\left.2.7 \mathrm{~cm}\right)$.

Among the 18 major calcareous species (Table 3), Bolivina seminuda, B. costata, Buliminella tenuata, $N$. auris, B. elegantissima, Bolivina pacifica and $V$. fragilis were the most abundant $(\geq 1 \%)$, and mainly inhabited the top centimetre of sediment (i.e. $\mathrm{ALD}_{5}$ was generally $<1.0 \mathrm{~cm}$ for each species; Fig. 6b). $\mathrm{ALD}_{5}$ values for these species were slightly deeper in sulfidic sediments than under the other redox conditions (Fig. 6b); however, only the $\mathrm{ALD}_{5}$ of Bolivina costata differed significantly among redox conditions (Table 5), being shallower under 'mixed' and deeper under sulfidic conditions. $N$. auris and $V$. fragilis also behaved this way but with a lower statistical significance. On the other hand, the only significant $(\mathrm{p}<$ 0.01 ) correlations between specific $A L D_{5}$ values and environmental factors (data not shown) were those of B. pacifica (positively correlated with Thioploca spp. biomass) and Buliminella elegantissima (negatively correlated with $\Sigma \mathrm{H}_{2} \mathrm{~S}_{[2]}$ ). These 2 species showed a wider range of vertical distribution in sediments under 'mixed' conditions.

\section{Canonical correspondence analyses}

Fig. 8 shows the $Q$ - and $R$-mode ordination triplot resulting from the CCA analyses, summarizing the variation of sampling sites (18 with complete environmental data) and average densities of the 18 major calcareous species (Table 3) in relation to environmental parameters. The first CCA axis (CCA1) accounted for $65.9 \%$ of species data variance and indicated a close affinity between the quality of $\mathrm{OM}$ (chl a/pha) and the redox state $\left(\Sigma \mathrm{H}_{2} \mathrm{~S}_{[2]}\right)$, as well as the negative relationship of these parameters with $\mathrm{OM}$ preservation (TOC, TN). The second axis (CCA2) explained $15.3 \%$ of species variation, relating BWDO and CPE. Based on this ordination, 4 different environmental settings can be characterized (Fig. 8). Quadrant I represents the sulfidic state associated with labile $\mathrm{OM}_{i}$ quadrant II represents the OMZ core based on its opposition to the BWDO vector; quadrant III corresponds to postoxic sediments with preserved OM (i.e. high $\mathrm{CPE}, \mathrm{TOC}, \mathrm{TN}$ ); and quadrant IV represents relatively oxygenated conditions. Inner shelf stations grouped in quadrant I, whereas the deepest stations off Callao and Pisco were positioned in quadrant II (Fig. 8a). Quadrant III contained middle and outer shelf stations, and only inner shelf stations from August 2009 and April 2010 were present in quadrant IV.

Foraminiferal species were distributed among the 'environmental quadrants' (Fig. 8b), resembling Spearman correlations (Table 4). Species of assemblage A were associated with quadrant $I_{i}$ species of assemblage B were close to the axes origin, suggesting a wider plasticity among the settings. The species of assemblage $\mathrm{C}$ were associated with quadrant III, and species of assemblages $\mathrm{D}$ and $\mathrm{E}$ were associated with quadrant II-with the exception of Buliminella elegantissima and Bolivina cf. striatula, respectively (both closer to the axes origin).

\section{DISCUSSION}

\section{Geochemical microhabitats in the sediment: redox conditions and $\mathrm{OM}$ quality}

The OMZ was well developed over the shelf during all sampling periods. In almost all samples, BWDO indicated severe dysoxia-microxia (0.01 to $0.2 \mathrm{ml} \mathrm{l}^{-1}$ ), but was slightly higher during the winter of 2009. Taking into account the low BWDO concentrations $\left(<0.4 \mathrm{ml} \mathrm{l}^{-1}\right)$ and the intense oxygen demand in coastal sediments with high export production (Levin et al. 2009), it could be inferred that the upper sedi- 


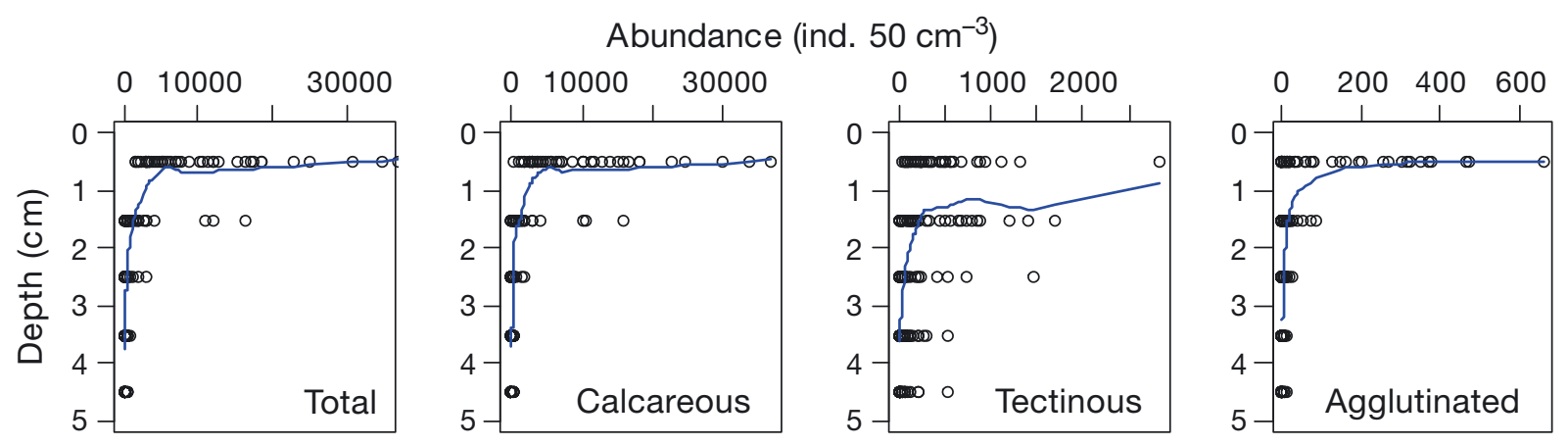

Fig. 7. Vertical distribution of benthic foraminifera: replicated abundances (without outliers) in sediment intervals for the total benthic foraminiferal community and the main groups (smooth line of abundance with depth in blue)

Table 5. Kruskal-Wallis $(H)$ ANOVA results for the average living depth for the top $5 \mathrm{~cm}\left(\mathrm{ALD}_{5}\right)$ sediment for the main $7 \mathrm{cal}-$ careous species in every redox state. Homogeneous groups determined by Wilcoxon-Mann-Whitney $U$-test. Value in bold indicates significance after correcting for multiple comparisons $(p<0.007)$. S: sulfidic; P: postoxic; M: mixed

\begin{tabular}{|c|c|c|c|c|c|c|}
\hline \multirow[t]{2}{*}{ Species } & \multicolumn{3}{|c|}{$\mathrm{ALD}_{5}($ mean $\pm \mathrm{SD})$} & \multicolumn{2}{|c|}{ Kruskal-Wallis } & \multirow{2}{*}{$\begin{array}{c}\text { Homogenous } \\
\text { groups }\end{array}$} \\
\hline & $\mathrm{S}$ & $\mathrm{M}$ & $\mathrm{P}$ & $H(4)$ & $\mathrm{p}$ & \\
\hline Bolivina costata & $0.9 \pm 0.3$ & $0.6 \pm 0.1$ & $0.8 \pm 0.3$ & 10.32 & 0.006 & $\mathrm{M}<\mathrm{P}<\mathrm{S}$ \\
\hline Nonionella auris & $0.8 \pm 0.1$ & $0.7 \pm 0.2$ & $0.6 \pm 0.2$ & 6.64 & 0.04 & \\
\hline Virgulinella fragilis & $0.9 \pm 0.3$ & $0.5 \pm 0.0$ & $0.8 \pm 0.4$ & 5.05 & 0.08 & \\
\hline Bolivina seminuda & $0.8 \pm 0.3$ & $0.6 \pm 0.1$ & $0.6 \pm 0.1$ & 3.49 & 0.17 & \\
\hline Buliminella tenuata & $0.8 \pm 0.2$ & $0.6 \pm 0.1$ & $0.6 \pm 0.1$ & 4.96 & 0.08 & \\
\hline Bolivina pacifica & $1.0 \pm 0.4$ & $0.7 \pm 0.4$ & $0.6 \pm 0.1$ & 3.72 & 0.16 & \\
\hline Buliminella elegantissima & $0.8 \pm 0.3$ & $0.7 \pm 0.4$ & $0.7 \pm 0.1$ & 1.52 & 0.47 & \\
\hline
\end{tabular}
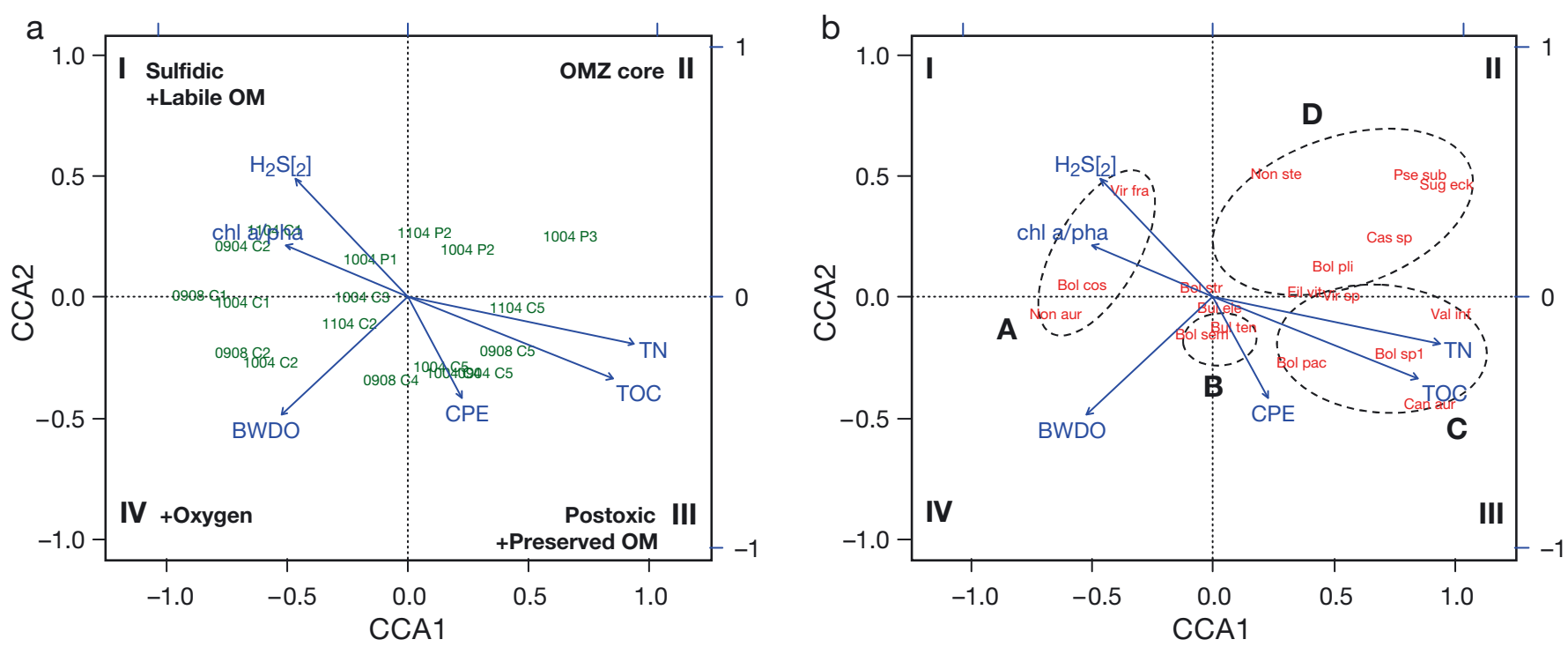

Fig. 8. Canonical correspondence analysis (CCA, scalings 1 and 2). Axes CCA 1 and CCA 2 are based on the total standing stocks (TSS) of the 18 most frequent calcareous foraminifora species; environmental variables shown as vectors. OM: organic matter; OMZ: oxygen minimum zone; TN: total nitrogen; TOC: total organic carbon; CPE: chloroplastic pigment equivalents; BWDO: bottom-water dissolved oxygen; chl a/pha: chlorophyll a to phaeopigments ratio; $\mathrm{H}_{2} \mathrm{~S}_{2}$ ] sulfide in top $2 \mathrm{~cm}$ porewater. Species abbreviations are as follows: Bol cos: Bolivina costata; Non aur: Nonionella auris; Vir fra: Virgulinella fragilis; Bol sem: Bolivina seminuda; Bul ten: Buliminella tenuata; Bol pac: Bolivina pacifica; Bol sp1: Bolivina sp. 1; ?Vir sp: ? Virgulina sp.; Val inf: Valvulineria inflata; Can aur: Cancris auriculus; Cas sp: Cassidulina sp.; Bul ele: Buliminella elegantissima; Non ste: Nonionella stella; Pse sub: Pseudoparrella subperuviana; Sug eck: Suggrunda eckisi; Eil vit: Eilohedra vitrea; Bol pli: Bolivina plicata; Bol str: Bolivina cf. striatula 
ments off Callao and Pisco were under highly reduced conditions during all sampling periods. Our results not only corroborate this, but help to determine different geochemical conditions under this oxygen-depleted setting.

Redox conditions differ spatially across the upper margin off central Peru and are associated with the quality of OM (Fig. 4). Inner shelf sediments were predominantly sulfidic and rich in fresh/labile phytodetritus (i.e. high $\mathrm{chl}$ a/pha ratios), whereas surface sediments of the middle and outer shelf and the upper slope were postoxic and presented highly preserved OM (i.e. high TOC and TN, Figs. 4 \& 8). Elevated primary productivity in the area and organic export to the bottom as sedimentation episodes (Gutiérrez et al. 2008) explain the high content of fresh/labile phytodetritus in the inner shelf. This condition, then, accounts for the subsequent production and accumulation of pore water sulfide by bacterial sulfate reduction, which appears to be the principal biochemical process for sedimentary OM oxidation in the shelf (Rowe \& Howarth 1985). Previous studies off Callao have documented highly labile OM in the inner shelf in contrast to the outer shelf, by using the microbial-C/TOC ratio (Cardich et al. 2012). In addition, Pérez (2012) determined elevated concentrations of the labile fraction of $\mathrm{OM}$ in the inner shelf sediments off Callao during April 2010. By contrast, surface sediments with low/null sulfides and high values of TOC, TN are typical of the outer shelf and upper slope off central Peru (Rowe \& Howarth 1985, Froelich et al. 1988, Böning et al. 2004). Low BWDO, high OM preservation and non-sulfidic pore waters indicate that the postoxic environment is characterized by the dominance of anaerobic respiration pathways mediated by the reduction of nitrate, manganese and iron (Berner 1981).

Even though organic sedimentation episodes accumulate the contents of labile OM, this OM is not preserved in the same manner across the upper margin. As anaerobic respiration is generally less efficient than aerobic respiration in $\mathrm{OM}$ oxidation (Froelich et al. 1988), bottom water 'suboxic' conditions favor the preservation and accumulation of sedimentary OM (Igarza 2012), as observed in the outer shelf and upper slope. Frequent ventilation of the water column enhances the efficiency of sedimentary OM cycling and other diagenetic processes in shallow environments (Gutiérrez et al. 2008, Scholz et al. 2011). This repercussion on sediment geochemistry is expressed by the low TOC and TN values observed in the inner shelf (Fig. 4). The redox fluctuation (oxic-sulfidic) in the inner shelf sediments then pre- vents the sedimentary OM from being similarly preserved as in the OMZ core (Dale et al. 2014).

Suits \& Arthur (2000) indicated that sulfide oxidation in the upper 10 to $15 \mathrm{~cm}$ of sediment is relevant in the central Peruvian slope. It has been postulated that sulfide oxidation coupled with nitrate reduction by giant filamentous bacteria Thioploca spp. explains the absence of sulfide in the outer shelf off Callao (Fossing 1990, Suits \& Arthur 2000), favoring the maintenance of postoxic conditions. Moreover, this process appears to be dominant and relevant for $\mathrm{N}$ cycling in the shelf (Bohlen et al. 2011). However, in this study, Thioploca spp. mats $\left(>30 \mathrm{~g} \mathrm{~m}^{-2}\right)$ were mainly found in the shallower stations off Callao and Pisco during April 2010 (post-El Niño period). Here, the geochemical conditions were re-establishing themselves after the high oxygenation event, corresponding to 'mixed' conditions (Fig. 4). Such mats were not present at deeper stations where postoxia prevailed. Thus, Thioploca spp. mats appear to respond to a sudden transition from oxic to anoxic conditions associated with seasonal- or El Niño-induced variations in chemistry (Suits \& Arthur 2000) rather than playing a role in establishing postoxia. This occurrence has been suggested in the study area by Gutiérrez et al. (2008), who also documented reduced Thioploca spp. biomass under oxic (El Niño) and anoxic (La Niña) conditions.

\section{Foraminiferal assemblages and geochemical microhabitats}

Benthic foraminifera densities $(>63 \mu \mathrm{m})$ in this study were within the range of those reported by previous studies in the region (Phleger \& Soutar 1973, Páez et al. 2001, Pérez et al. 2002, Høgslund et al. 2008, Mallon 2012) and other OMZ sediments at similar depths (e.g. the Arabian Sea; Gooday et al. 2000, Schumacher et al. 2007).

Our results corroborate the development of foraminiferal assemblages in relation to geochemical conditions. In the eutrophic, oxygen-depleted sediments off central Peru, food quality and pore water redox conditions also control the distribution of benthic foraminiferal assemblages, as indicated by the correlations ranks (Table 4) and CCA results (Fig. 8). This finding is consistent with species distribution patterns described in previous studies (Fig. 9). Further evidence regarding the importance of available food on the distribution of species assemblages, as well as the microhabitat of distinct species with respect to organic flux and pore water redox condi- 


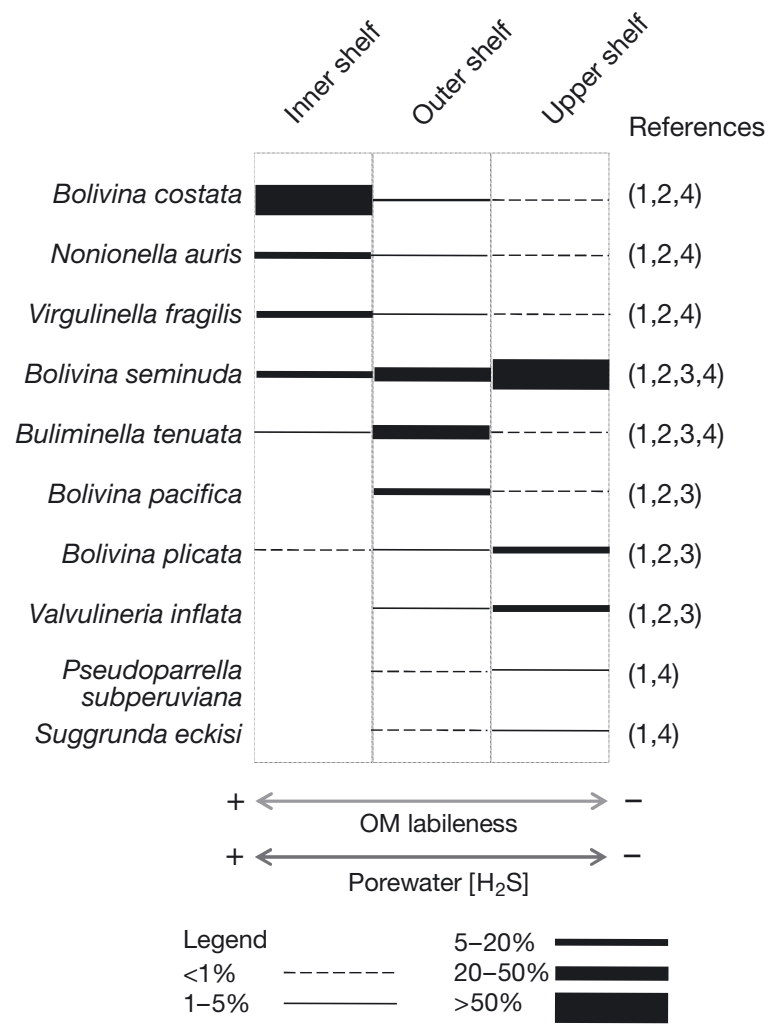

Fig. 9. Main foraminiferal species distributions presented on a percentage basis related to water depth from different sources. References: 1 , this study; 2, Cardich et al. (2012); 3, Pérez et al. (2002); 4, Resig (1990); 5, Mallon (2012)

tions has been presented in the last few years. However, most of this research was conducted in environments under meso-oligotrophic regimes, which differ greatly from the conditions in our study area (Eberwein \& Mackensen 2006, Fontanier et al. 2008, Koho et al. 2008, Mojtahid et al. 2010, Contreras-Rosales et al. 2012). Recently Caulle et al. (2014) determined 3 foraminiferal groups in a bathymetric-oxygen transect in northern Arabian Sea sediments, reflecting different environments from 'OMZ-core' to 'oxic' (below the OMZ).

Assemblage of sulfidic conditions/highly labile OM sediments

The species of assemblage A were strongly associated with coastal sediments containing high contents of labile OM and sulfide concentration. Previously, Heinze \& Wefer (1992) analyzed the >125 $\mu \mathrm{m}$ sediment fraction in a core from the Lima Basin $\left(11^{\circ} \mathrm{S}\right.$, ODP Leg 112, Site 680B, $253 \mathrm{~m}$ ) over a period covering the past $650000 \mathrm{yr}$, and reported high abundances of Bolivina costata and Nonionella auris asso- ciated with low oxygen conditions. Storage and intracellular respiration of nitrate in anoxic sediments has been reported for Nonionella cf. stella in the central Chilean shelf (Risgaard-Petersen et al. 2006, Høgslund et al. 2008), but this specimen may in fact have been $N$. auris because of their similar morphologies (Cardich et al. 2012). The occurrence and abundance of $N$. auris in the inner shelf stations could potentially be explained by the species' nitrate storage and denitrification capabilities, which are advantageous given the frequent ventilations that might prevent nitrate depletion in the bottom water. The physiology of Bolivina costata has not yet been researched. This species can be dominant or very abundant in the upper sublittoral zone off central (Khusid 1974) and northern Peru (Mayor 1998). Bolivina costata has even been found in the intertidal sandy sediments off Lima (Verano 1974), suggesting that this species can also thrive in oxygenated coastal settings. However, Verano (1974) did not distinguish live from dead fauna, and hence the individuals he found may have been transported to the shore by lateral advection. Still, the presence of $B$. costata and $N$. auris in shallow environments appears to be more important in eutrophic sediments such as Mejillones Bay (Páez et al. 2001, Ortlieb et al. 2000) and Pisco Bay (D. Romero pers comm.). Given its similar distribution with that of $N$. auris and the fact that other bolivinids can perform denitrification in oxygen-deficient sediments (Piña-Ochoa et al. 2010), the ability of $B$. costata to store and respire nitrate should be further investigated.

The contribution of Virgulinella fragilis to assemblage A was minimal. It was almost completely restricted to sulfidic sediments and could be considered characteristic of sulfidic environments. $V$. fragilis has been found in oxygen-deficient settings such as the Cariaco Basin (Bernhard 2003), bacterial mats in bathyal sediments in the Arabian Sea (Erbacher \& Nelskamp 2006), and the Aso-kai marine lagoon in Japan (Takata et al. 2005), among others (see references in Revets 1991 and Erbacher \& Nelskamp 2006). Leiter \& Altenbach (2010) characterized an assemblage dominated by $V$. fragilis as a proxy for 'anoxic sediments' (BWDO $=0 \mathrm{ml} \mathrm{l}^{-1}$ ) in the shelf off Namibia. Also, Erbacher \& Nelskamp (2006) related the occurrence of this species in a single core (>100 m depth, Arabian Sea) to the presence of a Beggiatoa/Thioploca mat, proposing $V$. fragilis as a paleo-proxy for filamentous macrobacterial mats. In our study, Thioploca spp. biomass at the points inhabited by $V$. fragilis was not high enough to be considered a mat, with exception of Stn C2 in April 2011 
(Fig. 4). As noted earlier, Thioploca spp. mats did not develop under sulfidic conditions. $V$. fragilis' tolerance to anoxic/sulfidic sediments can be attributed to kleptoplasts and symbiosis with sulfide-oxidant procariotic endobionts (Bernhard 2003). Moreover, V. fragilis also presents peroxisome-endoplasmic reticulum complexes that enables it to have the capability to use oxygen from $\mathrm{H}_{2} \mathrm{O}_{2}$ (Bernhard \& Bowser 2008). Our findings suggest that the local populations of $V$. fragilis in this area might also present such adaptations.

\section{Assemblage of postoxic/less labile OM sediments}

Bolivina pacifica and the other species of assemblage $\mathrm{C}$ were mainly limited to sediments under postoxia, containing high amounts of less labile OM. Bolivina pacifica, Valvulineria inflata and Cancris auriculus contribute to the 'oxygen-minimum biofacies' off Central Peru (Resig 1990). Off Callao (180 m depth), Phleger \& Soutar (1973) recorded specimens of $B$. cf. pacifica, which was by far the dominant species (95\%). Pérez et al. (2002) also found B. pacifica at the Peruvian OMZ core station $(305 \mathrm{~m})$ at a lower density than Bolivina seminuda. B. pacifica was also present in the sediments with Beggiatoa/Thioploca mats in the Arabian Sea (Erbacher \& Nelskamp 2006) and in the cold methane seeps of the California margin in lower densities than Buliminella tenuata (Rathburn et al. 2000). As suggested by Bernhard et al. (2010), ecological (ectobionts) and physiological (plasma membrane invaginations, clustered mitochondrias under pores) adaptations might explain the tolerance of Bolivina pacifica to oxygen-depleted sediments. Finally, B. pacifica was considered to be representative of the 'anoxic sediments' assemblage described by Leiter \& Altenbach (2010) for Namibia. Thus, while $B$. pacifica off Peru appear to be mainly restricted to the $\mathrm{OMZ}$ sediments (which tend to be postoxic rather than sulfidic), records from other regions suggest different adaptations.

\section{Assemblage of dominant species under postoxia}

The spatial distribution of Bolivina seminuda and Buliminella tenuata (assemblage B) was broad in this study and was marginally associated with CPE contents (Fig. 8). Both species were dominant in postoxic sediments with less labile/preserved OM, and also formed part of the 'oxygen-minimum biofacies' (Resig 1990). However, because of their distribution pat- terns, these species might be considered to be a different group than that of Bolivina pacifica. They were present under the sulfidic state as well, but not in abundance (with higher numbers for $B$. seminuda) (Fig. 6). B. seminuda is a common species in sediments under dysoxic bottom waters, such as the Santa Barbara Basin (Bernhard et al. 1997), off Oman (Hermelin \& Shimmield 1990) and in the eutrophic Mejillones Bay (Páez et al. 2001). Nevertheless, this species has been documented in more oxygenated zones with seasonal oxygen deficiency such as the Adriatic Sea, in low abundances through the year but with opportunistic peaks in summer (Barmawidjaja et al. 1992). With such a plastic distribution, B. seminuda might be responding to factors not considered in this study. Recent studies have shown that B. seminuda is a facultative anaerobic species that can store nitrate in its cells and respire it when oxygen is scarce (Piña-Ochoa et al. 2010). It is typically present in high densities and dominant in OMZ settings such as in the Arabian Sea (Gooday et al. 2000, Caulle et al. 2014), off Callao (Pérez et al. 2002, Cardich et al. 2012, Mallon 2012), off Central America (Smith 1963) and off California (Phleger \& Soutar 1973). In the Peruvian OMZ's core, the waters are usually nitraterich (e.g. Levin et al. 2002, Lam et al. 2009) and thus nitrate might be present in the topmost sediments, where it is used during denitrification and/or anammox (Bohlen et al. 2011, Dale et al. 2014). Over the inner shelf, dissolved nitrate is highly variable due to water column denitrification - driven by the decay of suspended OM associated with coastal upwelling productivity, and by thermal stratification or phytoplankton bloom sedimentation, which deplete oxygen-but also due to the poleward propagation of coastal trapped waves from the Equator, which deepen the nutricline (Gutiérrez et al. 2008). Apparently the dominance of $B$. seminuda towards the OMZ core might be strongly favored by the availability of dissolved nitrate, and perhaps lower biomasses of Thioploca spp. $\left(<30 \mathrm{~g} \mathrm{~m}^{-2}\right)$, together with the phytodetritus richness. As well, we suggest that the presence of $B$. seminuda in the inner shelf is promoted by coastal waves transporting dissolved nitrate, but that high abundances are prevented by the species' low tolerance of sulfidic conditions.

Conversely, Buliminella tenuata was not found to co-occur with Bolivina seminuda in all environments where it was reported. In the Santa Barbara Basin, both species were found throughout the entire oxygen gradient $\left(0.02\right.$ to $0.5 \mathrm{ml} \mathrm{l}^{-1}$ ) (Bernhard et al. 1997). Buliminella tenuata was less abundant than Bolivina seminuda in the OMZ core off Callao (Pérez 
et al. 2002). In the Arabian Sea, Buliminella tenuata accompanied $V$. fragilis in the sediment core with a Beggiatoa/Thioploca mat (Erbacher \& Nelskamp 2006). In the California margin, B. tenuata was found in clam beds of both cold methane seeps and in nonseeps sites, with a wide range of $\delta^{13} \mathrm{C}$ values (Rathburn et al. 2000). Bernhard et al. (2000) reported prokaryotic endobionts (possible denitrifiers; Bernhard et al. 2012) and peroxisomes, (as with $V$. fragilis) in individuals of $B$. tenuata from the Santa Barbara Basin. Such adaptations would allow B. tenuata to thrive under extreme oxygen deficiency. Nevertheless, it does not fully explain its dominance in the outer shelf and the decline in the upper slope in our study area (Fig. 9). We suggest that $B$. tenuata possesses an adaptation to intermediate conditions between the inner shelf and the upper slope related to OM composition. This would lead to competition for food with $B$. seminuda in the outer shelf. On other hand, $B$. tenuata might not thrive in the inner shelf because of its lower tolerance to sulfidic conditions than $B$. seminuda. Low living/dead ratios of both species (J. Cardich et al. unpubl. data) indicate potentially lower population growth rates as well.

\section{Other assemblages}

The species of assemblages D and E contributed little to the entire benthic foraminiferal community. Buliminella elegantissima, the dominant species of assemblage $\mathrm{D}$, displayed a high plasticity to environmental conditions, as it was concentrated in the axis origin of the CCA triplot and did not show significant correlations with any measured parameter (Fig. 8). This species was also part of the 'shelf biofacies' of Resig (1990) along with the species of assemblage A. According to Mallon (2012), B. elegantissima is mainly restricted to the less oxygenated upper margin off Peru (79 to $319 \mathrm{~m})$. However, Pérez et al. (2002) reported this species in the lower limit of the Peruvian OMZ (562 m) although its abundances peaked in the OMZ core. B. elegantissima has been reported in a range of slightly more oxygenated environments, such as the coastal zone of Mejillones Bay (21 to $61 \mathrm{~m})$, the shallowest station $\left(\right.$ BWDO $=0.51 \mathrm{ml} \mathrm{l}^{-1}$ ) harboring the highest densities (Páez et al. 2001). Despite this, assemblage D (without B. elegantissima) might be representative of OMZ-core conditions as these species were important at the deepest sites (Fig. 8). Eilohedra vitrea and Bolivina plicata of assemblage $\mathrm{E}$ appeared to be more associated with this OMZ-core assemblage as well.

\section{Exploring the microhabitat in vertical distribution}

Benthic foraminifera tend to concentrate near the sediment-water interface in reducing environments (Jorissen 1999), and are not abundant below the top 1 or $2 \mathrm{~cm}$ of the sediment. According to the TROX model, some specialist species are thought to live deeper than less tolerant species in mesotrophic sediments. That would mean that abundant surficial species under anoxia can inhabit deeper sediment intervals under less reducing conditions (e.g. postoxia). In this study, the bulk of the community and the most important calcareous species were concentrated in the first centimetre of sediment in all redox states. Some subsurface secondary peaks of abundance were seen for some species (e.g. V. fragilis; Cardich et al. 2012), suggesting that such species have more tolerance to reducing conditions.

Our results showed that $\mathrm{ALD}_{5}$ values did not correlate well with environmental conditions, and that only the $\mathrm{ALD}_{5}$ of Bolivina costata presented significant differences under different redox states (Table 5). However, when examining the $\mathrm{ALD}_{5}$ values, subtle differences in microhabitat between the species of assemblage A and the rest of species were evident. All main calcareous species were found in slightly deeper microhabitats in sulfidic sediments, which suggests an overall tolerance to high pore water sulfide. However, species from assemblage A are more specialized to sediments with copious quantities of pore water free sulfide, providing more evidence of possible physiological/symbiotic adaptations. Furthermore, the broader range of $\mathrm{ALD}_{5}$ values of $B$. costata and $V$. fragilis in postoxic sediments reflects their higher tolerance to more reducing conditions. The microhabitat of $N$. auris did not follow this pattern, and deepened from postoxic to sulfidic sediments. These differences might indicate preferences for OM composition.

The shallow microhabitat of the dominant species under postoxia presents an exception to the classical vertical distribution thought (i.e. the TROX model; Jorissen et al. 1995). The 'more suitable' redox conditions below the topmost sediment should allow deeper microhabitats, at least to the second centimetre. In contrast, benthic foraminifera protruded near the surface where labile OM of higher quality was available. Thus, the shallow $\mathrm{ALD}_{5}$ of Bolivina seminuda and Buliminella tenuata seems to be related mainly to the higher quality of labile OM at the surface. This feature reveals potential competition in sulfidic sediments with the dominant and more tolerant Bolivina costata and $N$. auris. In a similar way, $B$. 
pacifica, being less tolerant to free sulfide and thus restricted to postoxic sediments, was overwhelmed by the specialists $B$. seminuda and Buliminella tenu$a t a$, which exhibited similar $\mathrm{ALD}_{5}$ values. It remains difficult to depict the microhabitat of $B$. elegantissima given its plastic distribution.

Given the very shallow microhabitat that benthic foraminifera inhabit in organic rich sediments, it is evident that a species' vertical zonation (if it exists) is unlikely to be determined with classical subsampling (e.g. slicing). In this study, the highest resolution of slicing was $0.5 \mathrm{~cm}$ for the top $2 \mathrm{~cm}$. Under oxygen deficiency, species will occupy the first millimetre of sediment and might appear to share the same microhabitat. Nevertheless, the comparison of $\mathrm{ALD}_{5}$ values among redox locations suggests that OM quality may be important to microhabitat preference of benthic foraminifera in OMZ sediments.

\section{CONCLUSIONS}

Pore water redox and sedimentary OM quality regulate the distribution and microhabitat of calcareous benthic foraminifera in the sediments of the central Peruvian margin. In total, 5 assemblages of species were determined in this region, and the distribution of 4 of them responded in different degrees to geochemical indicators. Bolivina costata, Nonionella auris and Virgulinella fragilis (assemblage A) mainly inhabited sulfidic and labile OM-rich sediments typical of the inner shelf. Three assemblages dwelled in the middle and outer shelf and upper slope sediments, with high contents of less labile, preserved OM and very low values of pore water sulfide (postoxia). Assemblage C, represented by Bolivina pacifica, was characteristic of these sediments. Bolivina seminuda and Buliminella tenuata (assemblage B) largely dominated postoxic sediments but were frequent in sulfidic sediments as well. Since the dominance of Bolivina seminuda increased in the slope, we suggest that this species responds to $\mathrm{NO}_{3}$ availability and variability in the upper OMZ water column, although this hypothesis deserves further study. Conversely, Buliminella tenuata was more abundant in the outer shelf, and thus may respond to a condition related to OM composition. Assemblage D (Buliminella elegantissima and others) along with Eilohedra vitrea and Bolivina plicata from assemblage $\mathrm{E}$ tended to be associated with the OMZ core, as they commonly inhabited the deepest sites of the study with low BWDO values and postoxic conditions in the sediment. On the other hand, labile OM availability at the surface appears to be the primary factor determining vertical distribution in this environment. The microhabitat of the most abundant species was near the sediment-water interface, where more labile OM occurs independent of the redox condition.

Acknowledgements. We thank the Captains and crews aboard the RVs 'SNP 2' and 'José Olaya Balandra' during all the sampling cruises. We are grateful to the Instituto del Mar del Perú (IMARPE) for providing the laboratory and sampling facilities. We acknowledge Mrs. María del Carmen Morales and MSc Sergio Mayor for assistance with taxonomical analyses. We also thank Bch. Braulio Cueva for microbial analyses and $\mathrm{PhD}$ Carine Almeida for helpful comments in the redaction of this paper. The research was granted by the 'Cátedra CONCYTEC en Ciencias del Mar', sponsored by the Peruvian National Council of Science and Technology and the Universidad Peruana Cayetano Heredia, Master Program of Marine Sciences, and by the Peruvian Marine Research Institute (IMARPE) project MINIOX. It was also supported by collaborative projects between the Institut de la Recherche pour le Développement (IRD) and IMARPE: LMI DISCOH and Chaire Croisée PROSUR.

\section{LITERATURE CITED}

Barmawidjaja DM, Jorissen F, Puskaric S, Van der Zwaan GJ (1992) Microhabitat selection by benthic foraminifera in the northern Adriatic Sea. J Foraminifer Res 22: 297-317

Berner RA (1981) A new geochemical classification of sedimentary environments. J Sediment Petrol 51:359-365

Bernhard JM (2000) Distinguishing live from dead foraminifera: methods review and proper applications. Micropaleontology 46:38-46

Bernhard JM (2003) Potential symbionts in bathyal foraminifera. Science 299:861

Bernhard JM, Bowser SS (2008) Peroxisome proliferation in foraminifera inhabiting the chemocline: An adaptation to reactive oxygen species exposure? J Eukaryot Microbiol 55:135-144

Bernhard JM, Sen Gupta BK (1999) Foraminifera of oxygendepleted environments. In: Sen Gupta B (ed) Modern foraminifera. Kluwer Academic Publishers, Dordrecht, p 201-216

Bernhard JM, Sen Gupta BK, Borne PF (1997) Benthic foraminiferal proxy to estimate dysoxic bottom-water oxygen concentrations: Santa Barbara Basin, US Pacific continental margin. J Foraminifer Res 27:301-310

Bernhard JM, Buck KR, Farmer MA, Bowser SS (2000) The Santa Barbara Basin is a symbiosis oasis. Nature 403: $77-80$

> Bernhard JM, Habura A, Bowser SS (2006) An endobiontbearing allogromiid from the Santa Barbara Basin: implications for the early diversification of foraminifera. J Geophys Res 111:G03002, doi:10.1029/2005JG000158

Bernhard JM, Goldstein ST, Bowser SS (2010) An ectobiontbearing foraminiferan, Bolivina pacifica, that inhabits microxic pore waters: cell-biological and paleoceanographic insights. Environ Microbiol 12:2107-2119

Bernhard JM, Casciotti KL, McIlvin MR, Beaudoin DJ, Visscher PT, Edgcomb VP (2012) Potential importance of 
physiologically diverse benthic foraminifera in sedimentary nitrate storage and respiration. J Geophys Res 117: G03002, doi:10.1029/2012JG001949

Bohlen L, Dale AW, Sommer S, Mosch T and others (2011) Benthic nitrogen cycling traversing the Peruvian oxygen minimum zone. Geochim Cosmochim Acta 75:6094-6111

Böning P, Brumsack HJ, Böttcher ME, Schnetger B, Kriete C, Kallmeyer J, Borchers SL (2004) Geochemistry of Peruvian near-surface sediments. Geochim Cosmochim Acta 68:4429-4451

Borcard D, Gillet F, Legendre P (2011) Canonical ordination. In: Borcard D, Gillet F, Legendre P (eds) Numerical ecology with R. Springer, New York, NY, p 153-226

Bruland KW (2006) A review of the chemistries of redox sensitive elements within suboxic zones of oxygen minimum regions. Gayana (Concep) 70(Suppl 1):6-13

> Canfield DE, Thamdrup B (2009) Towards a consistent classification scheme for geochemical environments, or, why we wish the term 'suboxic' would go away. Geobiology 7 : 385-392

Cardich J, Morales M, Quipúzcoa L, Sifeddine A, Gutiérrez D (2012) Benthic foraminiferal communities and microhabitat selection on the continental shelf off central Peru. In: Altenbach AV, Bernhard JM, Seckbach J (eds) Anoxia: evidence for eukaryote survival and paleontological strategies, Vol 21. Springer, Dordrecht, p 323-340

> Caulle C, Koho KA, Mojtahid M, Reichart GJ, Jorissen FJ (2014) Live (rose bengal stained) foraminiferal faunas from the northern Arabian Sea: faunal succession within and below the OMZ. Biogeosciences 11:1155-1175

> Chavez FP, Messié M (2009) A comparison of eastern boundary upwelling ecosystems. Prog Oceanogr 83:80-96

> Cline JD (1969) Spectrophotometric determination of hydrogen sulfide in natural waters. Limnol Oceanogr 14: 454-458

> Contreras-Rosales LA, Koho KA, Duijnstee IAP, de Stigter HC, García R, Koning E, Epping E (2012) Living deepsea benthic foraminifera from the Cap de Creus Canyon (Western Mediterranean): faunal-geochemical interactions. Deep-Sea Res I 64:22-42

> Dale AW, Sommer S, Lomnitz U, Montes I and others (2014) Organic carbon production, mineralization and preservation on the Peruvian margin. Biogeosciences Discuss 11:13067-13126

> Eberwein A, Mackensen A (2006) Regional primary productivity differences off Morocco (NW-Africa) recorded by modern benthic foraminifera and their stable carbon isotopic composition. Deep-Sea Res I 53:1379-1405

Enge AJ, Witte U, Kucera M, Heinz P (2014) Uptake of phytodetritus by benthic foraminifera under oxygen depletion at the Indian margin (Arabian Sea). Biogeosciences 11:2017-2026

Erbacher J, Nelskamp S (2006) Comparison of benthic foraminifera inside and outside a sulphur-oxidizing bacterial mat from the present oxygen-minimum zone off Pakistan (NE Arabian Sea). Deep-Sea Res I 53:751-775

Fontanier C, Jorissen FJ, Lansard B, Mouret A and others (2008) Live foraminifera from the open slope between Grand Rhône and Petit Rhône Canyons (Gulf of Lions, NW Mediterranean). Deep-Sea Res I 55:1532-1553

> Fossing H (1990) Sulfate reduction in shelf sediments in the upwelling region off central Peru. Cont Shelf Res 10: 355-367

> Franco AC, Hernández-Ayón JM, Beier E, Garçon V and others (2014) Air-sea $\mathrm{CO}_{2}$ fluxes above the stratified oxygen minimum zone in the coastal region off Mexico. J Geophys Res 119:2923-2937

Froelich PN, Klinkhammer GP, Bender ML, Luedtke NA, Heath GR, Cullen D, Dauphin P (1979) Early oxidation of organic matter in pelagic sediments of the eastern equatorial Atlantic: suboxic diagenesis. Geochim Cosmochim Acta 43:1075-1090

> Froelich PN, Arthur MA, Burnett WC, Deakin M and others (1988) Early diagenesis of organic matter in Peru continental margin sediments: phosphorite precipitation. Mar Geol 80:309-343

Glantz SA (2002) Primer of biostatistics. McGraw-Hill Medical, New York, NY

Gooday AJ, Rathburn AE (1999) Temporal variability in living deep-sea benthic foraminifera: a review. Earth Sci Rev 46:187-212

> Gooday AJ, Bernhard JM, Levin LA, Suhr SB (2000) Foraminifera in the Arabian Sea oxygen minimum zone and other oxygen-deficient settings: taxonomic composition, diversity, and relation to metazoan faunas. Deep-Sea Res II 47:25-54

Grindell DS, Collen JD (1976) Virgulinella fragilis n. sp. (Foraminiferida) from Wellington Harbor, New Zealand. Rev Esp Micropaleontol 8:273-278

Gutiérrez D, Gallardo VA, Mayor S, Neira C and others (2000) Effects of dissolved oxygen and fresh organic matter on the bioturbation potential of macrofauna in sublittoral sediments off central Chile during the 1997/ 1998 El Niño. Mar Ecol Prog Ser 202:81-99

Gutiérrez D, Enríquez E, Purca S, Quipúzcoa L, Marquina R, Flores G, Graco M (2008) Oxygenation episodes on the continental shelf of central Peru: remote forcing and benthic ecosystem response. Prog Oceanogr 79:177-189

Gutiérrez D, Sifeddine A, Field D, Ortlieb L and others (2009) Rapid reorganization in ocean biogeochemistry off Peru towards the end of the Little Ice Age. Biogeosciences 6:835-848

Gutiérrez D, Quipuzcoa L, Yupanqui W, Marquina R and others (2010) Interacción de la zona de mínimo de oxígeno con la sedimentación de carbono orgánico y procesos bentónicos. Informe Anual LBM-Institute del Mar del Perú, Callao, p 1-44

- Heinze PM, Wefer G (1992) The history of coastal upwelling off Peru $\left(11^{\circ} \mathrm{S}\right.$, ODP Leg 112 , site $\left.680 \mathrm{~B}\right)$ over the past 650000 years. Geol Soc Lond Spec Publ 64:451-462

Helly JJ, Levin LA (2004) Global distribution of naturally occurring marine hypoxia on continental margins. DeepSea Res I 51:1159-1168

Hermelin JOR, Shimmield GB (1990) The importance of the oxygen minimum zone and sediment geochemistry in the distribution of recent benthic foraminifera in the northwest Indian Ocean. Mar Geol 91:1-29

> Høgslund S, Revsbech NP, Cedhagen T, Nielsen LP, Gallardo VA (2008) Denitrification, nitrate turnover, and aerobic respiration by benthic foraminiferans in the oxygen minimum zone off Chile. J Exp Mar Biol Ecol 359:85-91

Igarza MC (2012) Materia orgánica sedimentaria reciente del margen continental peruano: mecanismos de preservación y aplicaciones paleoceanográficas. MSc dissertation, Universidad Peruana Cayetano Heredia, Lima

Jannink NT, Zachariasse WJ, Van der Zwaan GJ (1998) Living (rose bengal stained) benthic foraminifera from the Pakistan continental margin (northern Arabian Sea). Deep-Sea Res I 45:1483-1513 
Jorissen FJ (1999) Benthic foraminiferal microhabitats below the sediment-water interface. In: Sen Gupta B (ed) Modern foraminifera. Kluwer Academic Publishers, Dordrecht, p 161-179

- Jorissen FJ, De Stigter HC, Widmark JGV (1995) A conceptual model explaining benthic foraminiferal microhabitats. Mar Micropaleontol 26:3-15

Khusid TA (1974) Distribution of benthic foraminifers off the west coast of South America. Oceanology 14:900-904

Koho K, Piña-Ochoa E (2012) Benthic foraminifera: inhabitants of low-oxygen environments. In: Altenbach AV, Bernhard JM, Seckbach J (eds) Anoxia: evidence for eukaryote survival and paleontological strategies, Vol 21. Springer, Dordrecht, p 249-285

Koho KA, García R, de Stigter HC, Epping E, Koning E, Kouwenhoven TJ, van der Zwaan GJ (2008) Sedimentary labile organic carbon and pore water redox control on species distribution of benthic foraminifera: a case study from Lisbon-Setúbal Canyon (southern Portugal). Prog Oceanogr 79:55-82

Lam P, Lavik G, Jensen MM, van de Vossenberg J, Schmid $M$ and others (2009) Revising the nitrogen cycle in the Peruvian oxygen minimum zone. Proc Natl Acad Sci 106: 4752-4757

Leiter C, Altenbach AV (2010) Benthic foraminifera from the diatomaceous belt off Namibia: characteristic species for severe anoxia. Palaentologia Electronica 13:11A

Levin LA (2003) Oxygen minimum zone benthos: adaptation and community response to hypoxia. Oceanogr Mar Biol Annu Rev 41:1-45

Levin LA, Gutiérrez D, Rathburn AE, Neira C and others (2002) Benthic processes on the Peru margin: a transect across the oxygen minimum zone during the 1997-98 El Niño. Prog Oceanogr 53:1-27

Levin LA, Ekau W, Gooday AJ, Jorissen F and others (2009) Effects of natural and human-induced hypoxia on coastal benthos. Biogeosciences 6:2063-2098

Mallon J (2012) Benthic foraminifera of the Peruvian and Ecuadorian continental margin. PhD dissertation, University of Kiel

Mayor S (1998) Foraminíferos calcáreos bénticos de la plataforma continental del norte peruano. Inst Mar Perú Inf 136:161-176

Middelburg JJ, Levin LA (2009) Coastal hypoxia and sediment biogeochemistry. Biogeosciences 6:1273-1293

> Mojtahid M, Griveaud C, Fontanier C, Anschutz P, Jorissen FJ (2010) Live benthic foraminiferal faunas along a bathymetrical transect $(140-4800 \mathrm{~m})$ in the Bay of Biscay (NE Atlantic). Rev Micropaleontol 53:139-162

Morales MDC, Field D, Mayor S, Gutiérrez D and others (2006) Variaciones de foraminíferos de los últimos 460 años en sedimentos laminados de la plataforma continental peruana. Bol Soc Geol Peru 101:5-18

Ortlieb L, Escribano R, Follegati R, Zúñiga $O$ and others (2000) Recording of ocean-climate changes during the last 2000 years in a hypoxic marine environment off northern Chile $\left(23^{\circ} \mathrm{S}\right)$. Rev Chil Hist Nat 73:221-242

Páez M, Zúñiga O, Valdés J, Ortlieb L (2001) Foraminíferos bentónicos recientes en sedimentos micróxicos de la Bahía Mejillones del Sur (23 S), Chile. Rev Biol Mar Oceanogr 36:129-139

Paulmier A, Ruiz-Pino D, Garçon V (2011) $\mathrm{CO}_{2}$ maximum in the oxygen minimum zone (OMZ). Biogeosciences 8: 239-252

> Pennington JT, Mahoney KL, Kuwahara VS, Kolber DD,
Calienes R, Chavez FP (2006) Primary production in the eastern tropical Pacific: a review. Prog Oceanogr 69: 285-317

Pérez A (2012) Composición bioquímica y distribución de la materia orgánica sedimentaria y sus efectos sobre la estructura comunitaria de la meiofauna en la plataforma continental frente a Callao. Bach. dissertation, Universidad Peruana Cayetano Heredia, Lima

Pérez ME, Rathburn AE, Levin LA, Deng WB (2002) The ecology of benthic foraminifera of the Peru oxygen minimum zone. In: Annual Meeting of the Geological Society of America, 27-30 Oct 2002, Denver, CO (Abstract)

Phleger FB, Soutar A (1973) Production of benthic foraminifera in three east Pacific oxygen minima. Micropaleontology 19:110-115

Piña-Ochoa E, Høgslund S Geslin E Cedhagen T and others (2010) Widespread occurrence of nitrate storage and denitrification among Foraminifera and Gromiida. Proc Natl Acad Sci USA 107:1148-1153

$>$ Rathburn AE, Corliss BH (1994) The ecology of living (stained) deep-sea benthic foraminifera from the Sulu Sea. Paleoceanography 9:87-150

> Rathburn AE, Levin LA, Held Z, Lohmann KC (2000) Benthic foraminifera associated with cold methane seeps on the northern California margin: ecology and stable isotopic composition. Mar Micropaleontol 38:247-266

Resig JM (1981) Biogeography of benthic foraminifera of the northern Nazca Plate and adjacent continental margin. Geol Soc Am 154:619-666

Resig JM (1990) Benthic foraminiferal stratigraphy and paleoenvironments off Peru, Leg 112. Proc Ocean Drill Progr Sci Results 112:263-296

> Revets SA (1991) The nature of Virgulinella Cushman, 1932 and the implications for its classification. J Foraminifer Res 21:293-298

Risgaard-Petersen N, Langezaal AM, Ingvardsen S, Schmid MC and others (2006) Evidence for complete denitrification in a benthic foraminifer. Nature 443:93-96

Rowe G, Howarth R (1985) Early diagenesis of organic matter in sediments off the coast of Peru. Deep-Sea Res 32: 43-55

Scholz F, Hensen C, Noffke A, Rohde A, Liebetrau V, Wallmann K (2011) Early diagenesis of redox-sensitive trace metals in the Peru upwelling area: response to ENSOrelated oxygen fluctuations in the water column. Geochim Cosmochim Acta 75:7257-7276

Schumacher S, Jorissen FJ, Dissard D, Larkin KE, Gooday AJ (2007) Live (rose bengal stained) and dead benthic foraminifera from the oxygen minimum zone of the Pakistan continental margin (Arabian Sea). Mar Micropaleontol 62:45-73

Shannon CE, Weaver W (1949) The mathematical theory of communication. University of Illinois Press, Urbana

Simpson EH (1949) Measurement of diversity. Nature 163: 688

Smith PB (1963) Recent foraminifera off central America. Quantitative and qualitative analysis of the family Bolivinidae. United States Geological Survey Professional Paper 429-A, Washington, DC

Stramma L, Johnson GC, Sprintall J, Mohrholz V (2008) Expanding oxygen-minimum zones in the tropical oceans. Science 320:655-658

Suits NS, Arthur MA (2000) Bacterial production of anomalously high dissolved sulfate concentrations in Peru slope sediments: steady-state sulfur oxidation, or tran- 
sient response to end of El Niño? Deep-Sea Res I 47: 1829-1853

Takata H, Seto K, Sakai S, Tanaka S, Takayasu K (2005) Correlation of Virgulinella fragilis Grindell and Collen (benthic foraminiferid) with near-anoxia in Aso-kai Lagoon, central Japan. J Micropalaeontol 24:159-167

Tapia R, Lange CB, Marchant M (2008) Living (stained) calcareous benthic foraminifera from recent sediments off Concepción, central-southern Chile $\left(\sim 36^{\circ} \mathrm{S}\right)$. Rev Chil Hist Nat 81:403-416

Thiel H (1978) Benthos in upwelling regions. In: Boje $R$,
Tomczak M (eds) Upwelling ecosystems. SpringerVerlag, Berlin, p 124-138

Uchio T (1960) Ecology of living benthonic foraminifera from the San Diego, California area. Cushman Found Foramin Res Spec Publ 5:1-72

Verano R (1974) Foraminíferos del litoral del departamento de Lima. Rev Peruana Biol 1:63-80

Woulds C, Cowie GL, Levin LA, Andersson JH and others (2007) Oxygen as a control on seafloor biological communities and their roles in sedimentary carbon cycling. Limnol Oceanogr 52:1698-1709

\section{Appendix.}

Table A1. Taxonomic information for the most important calcareous species documented in this study and references used for determination

\begin{tabular}{|c|c|}
\hline Species & Source \\
\hline Bolivina costata d'Orbigny, 1839 & Bolivina costata, Resig (1981), p. 647, plate 1, Fig. 1 \\
\hline Bolivina seminuda Cushman, 1911 & $\begin{array}{l}\text { Bolivina seminuda var. humilis, Resig (1990), p. 293, plate 2, } \\
\text { Figs. } 2 \text { \& } 3\end{array}$ \\
\hline Bolivina pacifica Cushman \& McCulloch, 1942 & $\begin{array}{l}\text { Bolivina pacifica, Uchio (1960), p. 48, plate 7, Fig. } 2 \\
\text { Bolivinellina pacifica, Resig (1990), p. 293, plate 2, Fig. } 4\end{array}$ \\
\hline Buliminella elegantissima d'Orbigny, 1839 & $\begin{array}{l}\text { Buliminella elegantissima, Uchio (1960), p. 31, plate 6, Fig. } 2 \\
\text { Buliminella elegantissima, Resig (1990), p. 292, plate 1, Fig. } 2\end{array}$ \\
\hline Buliminella tenuata Cushman, 1927 & $\begin{array}{l}\text { Fursenkoina glabra, Resig (1990), p. 293, plate 2, Fig. } 6 \\
\text { Bulimenella tenuata, Bernhard et al. (1997), p. 308, Fig. } 5 \text { G } \\
\text { Bulimina exilis, Jannink et al. (1998), p. 1497, plate 1, Fig. } 3\end{array}$ \\
\hline Nonionella auris d'Orbigny, 1839 & Nonionella auris, Resig (1990), p. 292, plate 1, Figs. 11-13 \\
\hline Virgulinella fragilis Grindell \& Collen, 1976 & $\begin{array}{l}\text { Virgulinella fragilis, Grindell \& Collen (1976), p. 274-277, plate 1, } \\
\text { Figs. 1-8 }\end{array}$ \\
\hline
\end{tabular}

Editorial responsibility: Christine Paetzold, Oldendorf/Luhe, Germany
Submitted: October 27, 2014; Accepted: July 3, 2015

Proofs received from author(s): August 30, 2015 